HOOFDSTUK VIII

\title{
Het conflict tussen Nederland en de Republiek Indonesië \\ Derde fase \\ Onvolledige politieke oplossing
}

\section{Inleiding en overzicht}

Het jaar 1949 bracht een grote wending in de verhouding tussen Nederland en de Republiek. In 1948 waren de Nederlandse beleidsmakers ervan uitgegaan dat men de soevereiniteit over Indonesië pas zou overdragen wanneer de Republiek geen eigen machtsapparaat meer zou bezitten. Begin 1949 dachten velen van hen dat de Republiek als politieke factor uitgeschakeld was door het in december tegen haar gelanceerde offensief (de tweede 'politionele actie'). Nederland had immers bijna al haar grondgebied bezet en had haar politieke leiders gevangen genomen. Maar eind 1949 droeg Nederland de soevereiniteit over aan een Indonesische federatie met Soekarno en Hatta als president en vicepresident en met het Republikeinse leger als kern van haar gewapende macht.

Deze paradoxale gang van zaken was in de eerste plaats te wijten aan het feit dat het decemberoffensief zowel militair als politiek een misgreep was. Militair, omdat de gevoerde 'speerpuntenstrategie' de Republikeinse strijdkrachten niet buiten gevecht kon stellen, maar ze juist bracht tot het voeren van een fellere en omvangrijkere guerrilla-oorlog dan ooit tevoren, waartegen de Nederlandse troepenmacht zich te weer moest stellen in een veel uitgestrekter gebied dan voordien. Politiek, omdat het offensief tot bijzonder ingrijpende bemoeienis van de Verenigde Naties leidde en omdat het een belangrijk deel van de Indonesische federalisten in de armen van de Republiek dreef.

$\mathrm{Al}$ kort na het begin van het offensief had de Veiligheidsraad Nederland opgeroepen tot staking van de vijandelijkheden en tot vrijlating van de gevangen genomen Republikeinse leiders. Omdat de Nederlandse regering hier 
nauwelijks gevolg aan gaf, nam de Raad op 28 januari 1949 een resolutie aan die Nederland in feite onder internationale curatele stelde. De Raad verlangde onder meer dat Nederland Soekarno en de zijnen onmiddellijk naar Jogja zou laten terugkeren. Verder zou Nederland opnieuw met de Republiek moeten onderhandelen. Die onderhandelingen zouden plaats moeten vinden onder auspiciën van een speciale VN-commissie voor Indonesië, de UNCI, die eigen aanbevelingen zou kunnen doen. De overdracht van de Nederlandse soevereiniteit aan de Verenigde Staten van Indonesië (VSI), de in het akkoord van Lingadjati voorziene Indonesische federatie, zou uiterlijk op 1 juli 1950 moeten plaatsvinden.

Terwijl Nederland dus op het internationaal-politieke toneel in een isolement beland was, raakte het ook geïsoleerd op het politieke toneel in Indonesië zelf. Sinds 1948 had de regering gedacht bij haar beleid tegenover de Republiek steeds te kunnen rekenen op steun van de leiders van de door Nederland gevormde deelstaten en autonome gebieden, de 'federalisten'. Maar na het decemberoffensief bleek de meerderheid van deze leiders niet bereid om buiten de Republiek om aan de vorming van de VSI mee te werken. Het werd duidelijk dat de Republiek niet als politieke factor uitgeschakeld was, ook al had het Nederlandse bestuur Soekarno, Hatta, Roem en enige andere Republikeinse voormannen op het eiland Bangka geïnterneerd.

Deze ontwikkelingen dwongen de Nederlandse regering tot het inslaan van een andere koers. Eind februari kwam zij met een nieuwe aanpak. Terwijl zij haar bezwaren tegen de resolutie van 28 januari handhaafde, verklaarde zij zich bereid de soevereiniteit al binnen enkele maanden over te dragen en nodigde zij zowel Soekarno als de federalisten uit om vertegenwoordigers aan te wijzen voor een in Den Haag te houden Rondetafelconferentie (RTC) over de voorwaarden voor die overdracht. Ook hief zij nu de internering van de Republikeinse leiders op, maar zij stond hen nog steeds niet toe naar Jogja te gaan.

Hierop besloten Soekarno en de zijnen op Bangka te blijven en geen gehoor te geven aan de uitnodiging voor de conferentie in Den Haag, zolang de Republikeinse regering niet naar Jogja kon terugkeren en zolang de UNCI niet de bevoegdheden zou kunnen uitoefenen die de Veiligheidsraad haar verleend had. Het overlegorgaan van de federalisten, de BFO, stelde zich achter de door Soekarno gestelde voorwaarden. Dit bracht de Nederlandse regering ertoe de mogelijkheid te onderzoeken om de Republikeinse leiders onder bepaalde voorwaarden toch naar Jogja te laten gaan. Onder auspiciën van de UNCI onderhandelde een door Van Roijen geleide delegatie van april tot juli in Batavia met een Republikeinse delegatie onder leiding van Roem. In mei leidde dit tot een voorlopig akkoord waarin de Nederlandse regering zich bereid verklaarde de Republikeinse leiders naar Jogja te laten terugkeren terwijl Soekarno en Hatta toezegden zich bij hun eigen regering te zullen 
inzetten voor beëindiging van de guerrilla-oorlog en voor deelname aan de RTC. Eind juni werd Jogja door de Nederlandse troepen verlaten, in juli keerden Soekarno en Hatta daar terug, begin augustus kondigden Nederland en de Republiek een bestand af en op 23 augustus begon de RTC in Den Haag. Daarbij leidde Hatta zelf de Republikeinse delegatie. Men streefde ernaar de soevereiniteitsoverdracht voor het eind van het jaar te doen plaatsvinden.

Voor een groot deel van het Nederlandse publiek viel deze gang van zaken moeilijk te begrijpen. Men dacht dat Nederland in de tweede 'politionele

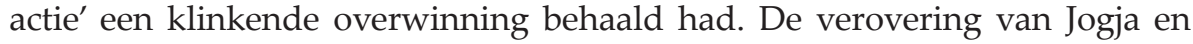
de gevangenneming van Soekarno en Hatta golden als de grootste successen van die actie; het ongedaan maken daarvan wekte de indruk dat de actie nergens voor gediend had. Toch leidde de koerswijziging van de regering niet tot grootscheeps protest. Het conflict in Indonesië had nu al bijna vier jaar geduurd en de meeste Nederlanders waren het moe. Zij hoopten na deze onverwachte wending vooral op een spoedige thuiskomst van de uitgezonden militairen.

Anders dan in 1945 en 1946 was men er in Nederland nu algemeen aan gewend dat Indonesië een onafhankelijk land zou worden, hoe pijnlijk velen dit ook vonden. De jarenlang door het Nationaal Comité Handhaving Rijkseenheid aangevoerde oppositie tegen de dekolonisatie van Indonesië had in feite het pleit verloren. $\mathrm{Nu}$ deze oppositie de scheiding tussen het Koninkrijk en Indonesië op zichzelf niet meer kon tegenhouden, spande zij zich in om toch nog het meest oostelijke deel van de archipel binnen het Rijk te houden. Onder meer voerde zij propaganda-acties die de indruk wekten dat de bevolking van de Minahasa, de Molukken en Timor geen deel van de VSI wilde worden, maar met Nederland verbonden wilde blijven. Ook bevorderde zij acties voor handhaving van de band tussen Nederland en Nieuw-Guinea.

De RTC was formeel een conferentie tussen drie partijen: Nederland, de $\mathrm{BFO}$ en de Republiek. Van te voren hadden de BFO en de Republiek echter onderling overleg gepleegd, waardoor de kaarten voor de RTC al grotendeels geschud waren. Onder meer hadden ze afgesproken dat de naam van de te stichten onafhankelijke federale staat zou luiden Republiek der Verenigde Staten van Indonesië (RVI) en dat deze staat haar soevereiniteit niet alleen aan Nederland zou ontlenen maar ook aan de in 1945 gestichte Republiek Indonesië. Ook hadden ze besloten dat de Nederlandse landstrijdkrachten Indonesië volledig zouden moeten verlaten en dat de TNI de kern zou worden van de gewapende macht van de RVI.

De RTC duurde tot 2 november. Met hulp van de UNCI werden de delegaties het uiteindelijk eens over bijna alle kwesties die met de scheiding tussen Nederland en Indonesië verband hielden. De getroffen regelingen schiepen gunstige voorwaarden voor de voortzetting van de Nederlandse economische actitiviteiten in Indonesië. Aan de andere kant liet Nederland op staatkun- 
dig en militair gebied veel van zijn oorspronkelijke plannen varen. De al in het akkoord van Linggadjati voorziene Nederlands-Indonesische Unie werd slechts een licht samenwerkingsverband.

Over één kwestie werd men het op de RTC niet eens: de toekomst van Nieuw-Guinea. De achtergrond hiervan lag op het terrein van de parlementaire rekenkunde. Naar Nederlands staatsrecht kon de soevereiniteit over Indonesië niet worden overgedragen zonder instemming van een tweederde meerderheid in het parlement. Voor het behalen van die meerderheid was ook enige steun nodig van parlementariërs die Nieuw-Guinea bij Nederland wilden houden. Op de RTC nam Nederland daarom het standpunt in dat dit gebied van de overdracht uitgezonderd moest worden. Om de conferentie niet op dit ene punt te laten stranden besloten de delegaties deze kwestie een jaar uit te stellen.

Na de sluiting van de RTC bereidden vertegenwoordigers van de Republiek en de federalisten de stichting van de RVI voor. Daarbij kozen ze Soekarno en Hatta tot president en vicepresident. Op 27 december 1949 droeg Nederland de soevereiniteit over en maakte de Nederlandse rood-wit-blauwe vlag op het paleis in Batavia plaats voor de Indonesische rood-witte vlag. De volgende dag betrok Soekarno het paleis.

Het op de RTC getroffen complex van regelingen paste in het kader van het akkoord van Linggadjati. Er zijn geen aanwijzingen dat de Republiek in juli 1947 en in december 1948 niet bereid geweest zou zijn Nederland even ver tegemoet te komen als nu. Niettemin heeft de Nederlandse regering toen gemeend dat Nederland geen andere keus had dan een aanval op de Republiek. In 1947 en 1948 ontbrak aan Nederlandse kant dus nog de bereidheid tot een politieke oplossing als uiteindelijk in 1949 tot stand gekomen is. Twee factoren hebben daarbij een rol gespeeld. Ten eerste kostte het de meeste Nederlanders enige jaren om aan de gedachte te wennen dat Indonesië werkelijk onafhankelijk zou worden. Daarom waren de Nederlandse beleidsmakers ook na het akkoord van Linggadjati blijven streven naar staatsrechtelijke en militaire waarborgen om Nederland nog lange tijd invloed op de gang van zaken binnen Indonesië te geven. Ten tweede beschikte Nederland toen in Indonesië over een grote strijdmacht. Dit werkte de gedachte in de hand dat men het Nederlandse militair-technische overwicht kon benutten om de nagestreefde waarborgen te verkrijgen. Het Nederlandse offensief van december 1948 was de definitieve 'proef op de som'. Het bleek een fiasco te zijn.

Hoewel de meeste Nederlanders in 1949 wel inzagen dat de onafhankelijkheid van Indonesië onvermijdelijk was, betekende dit voor velen een traumatische ervaring. Voor een deel van hen leek het behoud van een stukje van het vroegere imperium de pijn wat te kunnen verzachten. De campagne voor handhaving van de band tussen Nederland en Nieuw-Guinea ontleende hieraan haar kracht. De in verband daarmee op de RTC gemaakte voorlopige 
uitzondering voor dat gebied had tot gevolg, dat het RTC-akkoord geen volledige oplossing inhield van het geschil tussen Nederland en de Republiek. Zij vormde het begin van het conflict over Nieuw-Guinea, dat noodlottig zou blijken voor het voortbestaan van een nauwe band tussen Nederland en Indonesië.

\section{De militaire situatie na het tweede Nederlandse offensief}

Al sinds begin december 1948 waren de politieke en militaire leiders van de Republiek ervan uitgegaan dat een groot Nederlands offensief voor de deur stond. Ze hadden echter niet verwacht dat Nederland zou aanvallen terwijl het nog betrokken was bij overleg met de Republiek via de Amerikaanse vertegenwoordiger Cochran. Daardoor was de aanval op 19 december toch als een verrassing gekomen; in het bijzonder was de hoofdstad Jogja weerloos geweest tegen de Nederlandse luchtoperatie. Daarentegen hadden de Republikeinse strijdkrachten tijdens het verdere verloop van het decemberoffensief en daarna veel baat gehad van eerder getroffen voorbereidingen. Vooral kolonel Nasoetion had zich in de loop van 1948 ingespannen om de tijdens het Nederlandse offensief van juli 1947 opgedane ervaringen te benutten voor de voorbereiding van doeltreffende guerrilla-oorlogvoering in geval van een nieuw offensief. Zo was aan ieder TNI-onderdeel een operatiegebied toegewezen waarheen het zich zou moeten terugtrekken wanneer Nederland de Republiek weer zou aanvallen. Het was de bedoeling dat de plaatselijke bevolking de militairen dan zou onderhouden; vaak ging het om gebieden waar veel leden van het onderdeel vandaan kwamen. De aangewezen operatiegebieden lagen niet alleen binnen het gebied dat na het offensief van 1947 onder Republikeins bestuur gebleven was, maar ook binnen het toen onder Nederlands bestuur gekomen gebied. De meest spectaculaire verplaatsing na het tweede Nederlandse offensief was die van de Siliwangidivisie, die er in de loop van twee maanden in slaagde zich met behoud van haar organisatiestructuur uit Midden-Java naar het Soendanese deel van West-Java terug te trekken.

Tussen de naar West-Java trekkende TNI-militairen bevond zich ook een Nederlandse dienstplichtige soldaat, Jan Princen (die zich vaak Poncke Princen noemde). Hij had van begin af aan sympathie voor de Indonesische vrijheidsstrijd gevoeld en was in oktober 1948 gedeserteerd en naar Republikeins gebied gegaan om zijn diensten in Jogja aan te bieden. Daar had men hem echter niet vertrouwd, met het gevolg dat hij gevangen gezet was. Toen Jogja op 19 december werd aangevallen, had een officier van de Siliwangidivisie hem vrijgelaten en voor de keus gesteld hetzij mee te trekken naar West-Java hetzij terug te keren naar het Nederlandse leger. Princen had het eerste geko- 
zen en zich bij de Republikeinse strijders gevoegd. In West-Java gaf hij onder meer leiding aan overvallen op ondernemingswachten en politieposten. Door vrijwillig gewapenderhand aan de Republikeinse strijd deel te nemen maakte hij zich bij een groot deel van de Nederlandse militairen uitzonderlijk gehaat.

Het feit dat de Nederlandse strijdkrachten de verplaatsing van de Siliwangidivisie naar West-Java niet konden verhinderen illustreert dat Nederland de militaire situatie na het decemberoffensief niet meester was. Terwijl het voordat het offensief begon al over te weinig troepen beschikt had om in de onder Nederlands bestuur staande gebieden een eind te maken aan het plaatselijk verzet, moest het nu met diezelfde troepenmacht een veel groter gebied bestrijken. Terwijl het reguliere Republikeinse leger sinds januari 1948 zelden openlijk aan anti-Nederlandse acties deelgenomen had omdat toen een formeel bestand van kracht was, kon de TNI zich nu volledig voor de strijd inzetten omdat Nederland dit bestand verbroken had. Na hun hergroepering kregen de Republikeinse troepen meestal voldoende steun van de bevolking om een doeltreffende guerrilla te voeren. Dit gold ook voor Oost-Java, waar de TNI nog kort tevoren de communistische Madioenopstand bloedig onderdrukt had.

Dat de guerrilla van nu af aan op Java en Sumatra veel meer gebied dan vroeger omvatte kwam niet alleen omdat de strijd zich uitbreidde tot die delen van de Republiek waar de Nederlandse troepen tijdens het decemberoffensief in doorgedrongen waren. De guerrilla leefde namelijk ook op in verscheidene gebieden die al lange tijd onder Nederlands bestuur stonden. Dit werd vergemakkelijkt door het feit dat sinds medio 1948 duizenden TNI-militairen in die gebieden geïnfiltreerd waren. Wel kampten de Republikeinse troepen met tekorten aan vuurwapens en munitie (dit was de hoofdreden voor hun overvallen op politieposten en ondernemingswachten), maar ze beschikten vaak over ruime voorraden explosieven, met inbegrip van landmijnen en vliegtuigbommen. Die gebruikten ze vooral voor het verstoren van de Nederlandse verbindingsroutes door het ondermijnen van wegen en opblazen van bruggen. De Nederlandse militairen konden deze routes, die als gevolg van het offensief sterk uitgerekt waren, niet afdoende beveiligen. Vaak gebeurde het dat een door de Nederlandse genie herstelde brug al binnen enkele dagen opnieuw vernield werd. Sommige Nederlandse posten raakten zo geïsoleerd dat men ze niet meer regelmatig kon bevoorraden.

Bij de voorbereiding van het decemberoffensief was generaal Spoor ervan uitgegaan dat hij het daarna nog resterende Republikeinse verzet in een periode van drie tot zes maanden zou kunnen bedwingen. Evenals de meeste KNIL-officieren en veel BB-ambtenaren dacht hij dat slechts een kleine minderheid van de Indonesische bevolking Republikeinsgezind was en dat de meerderheid alleen naar rust en orde verlangde. Daarom verwachtte hij dat de guerrilla grotendeels zou uitdoven wanneer Nederland het vijandelijke actiecentrum in Jogja eenmaal uitgeschakeld had. Geheel in strijd met deze ver- 
wachting bleek het decemberoffensief ertoe te leiden dat de Nederlandse troepen te maken kregen met een fellere en omvangrijkere guerrillastrijd dan ooit tevoren. Er sneuvelden nu ook meer militairen aan Nederlandse kant: ruim vijfhonderd in de eerste drie maanden van 1949 (terwijl er minder dan twaalfhonderd gesneuveld waren in de drie jaar voor de tweede politionele actie). Overigens waren de meeste slachtoffers van het Republikeinse verzet geen Nederlandse militairen maar Indonesische burgers die met het Nederlandse gezag samenwerkten. Dat zulke samenwerking voor die Indonesiërs het risico meebracht door het verzet uit de weg geruimd te worden maakte het voor de Nederlandse autoriteiten extra moeilijk om de tijdens het offensief bezette gebieden onder hun bestuur te brengen. Buiten de steden bleven grote delen van die gebieden onder Republikeins bestuur staan.

Ook bij de Indonesiërs die tegen Nederland streden deden zich onderlinge conflicten voor. In West-Java had de door Kartowoewirjo geleide Daroel Islam-beweging zich in de loop van 1948 tot de belangrijkste kern van het anti-Nederlandse verzet ontwikkeld, nadat het reguliere Republikeinse leger dit gebied op grond van het Renville-akkoord verlaten had (zie pp. 570). Na de bezetting van Jogja door het Nederlandse leger meende Kartosoewirjo dat de Republiek had opgehouden te bestaan en riep hij zijn aanhang op zich in te zetten voor de stichting van een Islamitische Indonesische staat. Toen de Siliwangidivisie begin 1949 in West-Java terugkeerde, raakte zij dan ook al spoedig in conflict met de strijdkrachten van de Daroel Islam. Dit groeide uit tot een soort driehoeksoorlog tussen de Daroel Islam, Nederland en de Republiek, maar het leidde ook tot toenadering tussen de Siliwangidivisie en de Republikeinsgezinde regering van de deelstaat Pasoendan.

In Oost-Java leidde een heel andere politieke tegenstelling tot een broederstrijd met Tan Malaka en diens aanhang. De regering van de Republiek had deze legendarische revolutionair kort voor het uitbreken van de Madioenopstand uit gevangenschap ontslagen. In november was hij zich gaan inzetten voor coördinatie van het guerillaverzet tegen de algemeen verwachte Nederlandse aanval op de Republiek. Het lukte hem in Oost-Java enige tientallen bataljons tot samenwerking te brengen in een verbond genaamd Gaboengan Pembela Proklamasi (GPP, Verbond van Verdedigers van de Proclamatie). Toen het Nederlandse leger in december Jogja veroverde en de leiders van de Republiek gevangen nam, dacht Tan Malaka evenals Kartosoewirjo dat hun rol uitgespeeld was. Onder bescherming van de GPP begon hij een felle propagandacampagne, waarin hij verklaarde dat de politiek van Soekarno en Hatta volledig gefaald had en dat hij nu de leiding van de vrijheidsstrijd op zich nam. Andere TNI-eenheden keerden zich tegen hem; in februari 1949 werd hij gevangen genomen en gefusilleerd, maar het duurde maanden voordat zijn dood bekend werd. Volgelingen van hem bleven in verschillende delen van Java actief met het organiseren van een linkse oppositie, 
soms opnieuw onder de naam Pembela Proklamasi, maar een belangrijke rol speelden ze niet meer.

De verheviging van de guerrillastrijd na het decemberoffensief logenstrafte de theorie dat dit offensief een eind aan de Republiek gemaakt had, maar van die verheviging drong in de eerste maanden weinig tot de buitenwereld door. Om voor meer publiciteit te zorgen pleegde de TNI een spectaculaire aanval op de bezette hoofdstad van de Republiek. Bij de voorbereiding daarvan voerden de sultan van Jogja en opperbevelhebber Soedirman overleg via de commandant van het operatiegebied, luitenant-kolonel Soeharto. In de vroege ochtend van 1 maart openden TNI-militairen die in het geheim de stad waren binnengegaan de aanval op de Nederlandse bezetting, terwijl deze ook van buiten de stad werd aangevallen. In totaal namen ongeveer tweeduizend Republikeinse soldaten aan de aanval deel. Zij leden zware verliezen, maar in het centrum van Jogja slaagden zij er in zich zes uur lang te handhaven; om hen te verdrijven moest het Nederlandse garnizoen versterkingen van elders aanvoeren. Militaire waarnemers van de UNCI waren getuigen van deze gebeurtenis en rapporteerden hierover aan de Veiligheidsraad.

\section{De politieke situatie na het tweede Nederlandse offensief}

Toen de Nederlandse regering in december 1948 besloot tot een grote militaire actie tegen de Republiek, ging zij er van uit dat die actie gevolgd zou worden door de instelling van een federale interimregering (FIR) op basis van de regeling Bewind Indonesië in Overgangstijd (BIO). Volgens deze regeling, afgekondigd aan de vooravond van de actie, zou de interimregering uit Indonesiërs bestaan, maar zou daarnaast een Nederlandse Hoge Vertegenwoordiger functioneren met belangrijke bevoegdheden, waaronder het opperbevel over de strijdkrachten en het recht om die ook zonder instemming van de interimregering in te zetten voor de handhaving van orde en veiligheid. De instelling van de FIR zou een overgangstijd inluiden die zou duren tot de formele oprichting van de soevereine Verenigde Staten van Indonesië.

Bij haar besluit tot militaire actie tegen de Republiek had de regering echter nagelaten duidelijk het politieke doel te bepalen waar die actie toe zou moeten dienen. Dit was niet onbelangrijk, want over de politieke doelstelling werd binnen de regering verschillend gedacht. Sommigen, onder wie de minister van buitenlandse zaken Stikker, zagen de militaire actie als middel om de Republiek van 'extremistische' elementen te zuiveren, waarna zij dan de haar toegedachte plaats zou kunnen innemen in de te vormen Indonesische federatie. Anderen, onder wie de minister van overzeese gebiedsdelen Sassen, zagen de actie als middel om de Republiek als staatkundige organisatie te liquideren teneinde de weg vrij te maken voor vorming van die federatie zonder de 
Republiek. Dit was ook precies wat Beel, de Hoge Vertegenwoordiger van de Kroon in Batavia, en Spoor, de legercommandant, met het december-offensief beoogd hadden. Daarentegen had minister-president Drees, onder wiens verantwoordelijkheid het besluit tot militaire actie genomen was, in het geheel geen politiek doel op het oog gehad. Naar hij later verklaarde ging het hem er niet om militair een politieke beslissing af te dwingen, maar wilde hij alleen dat er een eind zou komen aan de Republikeinse bestandsschendingen. Hoe weinig aandacht zijn regering destijds gegeven had aan het politieke vervolg op de voorgenomen militaire actie, blijkt ook uit het feit dat men zelfs niet besproken had wat men met de leiders van de Republiek zou doen als die in Nederlandse handen zouden vallen.

Toen het decemberoffensief eenmaal gelanceerd was, leidde het niet tot versterking maar tot ernstige verzwakking van de politieke positie van Nederland. Dit begon al met de scherpe reactie van de Verenigde Naties en de afhoudende opstelling van een deel van de federalisten (zie pp. 605-10). De Nederlandse regering had zowel het één als het ander kunnen voorzien. Begin december had de Amerikaanse regering haar op harde toon gewaarschuwd tegen een aanval op Jogja. In dezelfde tijd had Sassen voorspeld dat de meeste federalisten geen verantwoordelijkheid zouden willen nemen voor een interimregering zonder de Republiek. De regering had niettemin besloten tot de militaire actie die zij nu eenmaal onvermijdelijk vond. Het ontbreken van een vooraf overeengekomen politiek plan droeg ertoe bij dat zij nu zonder vaste lijn op de nieuwe ontwikkelingen reageerde. In de loop van enkele maanden zouden die ontwikkelingen, zowel op het internationaal-politieke toneel als binnen Indonesië zelf, haar tot beleidswijzigingen brengen in strijd met alles wat met het offensief beoogd was.

In januari 1949 beseften de meeste Nederlanders nog niet hoe zwak de Nederlandse positie geworden was. Beel nam het standpunt in dat de militaire actie een eind gemaakt had aan het bestaan van de Republiek als staatkundige organisatie, dat daardoor ook het geschil tussen Nederland en de Republiek had opgehouden te bestaan en dat daarmee automatisch de grond was ontvallen aan de bemoeienis van de Verenigde Naties met dat geschil. Hij wilde het hele grondgebied van de Republiek 'federaliseren' door het gedeeltelijk bij bestaande deelstaten en gedeeltelijk bij nog op te richten deelstaten onder te brengen. Met het oog daarop bereidden Nederlandse bestuursambtenaren en KNIL-officieren in de op de Republiek veroverde gebieden de vorming van nieuwe staatkundige eenheden voor. Generaal Spoor handhaafde zijn plannen voor de opbouw van de strijdkrachten van de VSI waarin hij geen enkele plaats aan de TNI toekende. De Nederlandse pers in Indonesië bracht alarmerende berichten over de op Republikeins gebied aangetroffen honger en ontwrichting; meestal schreef men deze toestanden niet toe aan de door Nederland tegen de Republiek toegepaste economische blokkade, maar aan 
wanbeheer van de Republikeinse autoriteiten. In aansluiting op die berichten werd met steun van de Nederlandse legerleiding een charitatieve campagne georganiseerd voor hulp aan de bevolking in de 'bevrijde' gebieden. Aan het hoofd van deze campagne kwam de echtgenote te staan van Abdoelkadir, de vroegere plaatsvervanger van Van Mook. De grote publiciteit die aan haar rol gegeven werd deed vermoeden dat de legerleiding aan haar man de toekomstige functie van president van Indonesië toegedacht had.

De toekomstplannen van Beel en Spoor misten echter voldoende reële basis. Zo kon men het geschil met de Republiek niet eenvoudig elimineren door op basis van de BIO-regeling een FIR in te stellen. Daartoe was men afhankelijk van de medewerking van de federalisten, maar die besloten al op 13 januari eerst met prominente Republikeinen te gaan praten. Te doen alsof de Republiek niet meer bestond was volstrekt irreëel, niet alleen omdat de Verenigde Naties haar nog steeds als partij bij het geschil met Nederland beschouwden, maar ook omdat zij nu eenmaal voor een groot aantal Indonesiërs de belichaming van hun streven naar nationale onafhankelijkheid vormde.

Bovendien was de Republiek niet alleen als idee maar ook als realiteit blijven bestaan. Afgezien van het feit dat de Nederlandse troepen het noordelijkste deel van Sumatra (Atjeh) in het geheel niet betreden hadden, hadden zij ook in de Republikeinse gebieden waarin ze wel doorgedrongen waren de TNI niet verslagen, noch op Sumatra noch op Java. In de meeste van die gebieden functioneerde buiten de steden nog het Republikeinse bestuur. Het centrale Republikeinse regeringsgezag werd vertegenwoordigd door de op Sumatra gevestigde noodregering van Sjafroedin Prawiranegara, die ook contact onderhield met Republikeinse vertegenwoordigers in het buitenland. Op Java werd dit gezag vertegenwoordigd door vijf ministers uit het kabinetHatta die na het decemberoffensief buiten Nederlandse handen gebleven waren; de noodregering benoemde dit vijftal tot commissariaat van de centrale regering, met Soekiman als voorzitter. Namens de zieke opperbevelhebber Soedirman nam zijn plaatsvervangend stafchef kolonel Simatoepang tijdelijk zijn functies waar, in overleg met kolonel Nasoetion, de commandant van de Republikeinse strijdkrachten op Java. Zowel op Java als op Sumatra beschikte men aan Republikeinse kant over verscheidene radiozenders; met behulp van die zenders en van talloze koeriers slaagden bestuurders en militairen er steeds beter in onderling contact te onderhouden.

\section{Nederlands aanbod tot vervroegde overdracht van de soevereiniteit}

De wijzigingen van het Nederlandse beleid in de eerste maanden van 1949 betroffen onder meer de formele opstelling tegenover de leiders van de Republiek. Beel ging er oorspronkelijk van uit dat er geen sprake meer kon 
zijn van politiek overleg met lieden als Soekarno en Hatta. Wel vond hij het wenselijk in de FIR ook enige uit de Republiek afkomstige figuren op te nemen, maar die zou men niet als vertegenwoordigers van de Republiek mogen behandelen omdat deze immers volgens hem had opgehouden te bestaan. Drees dacht hier tijdens zijn bezoek aan Batavia in januari anders over: hij vond het zo belangrijk de Republikeinse topfiguren bij het overleg over de toekomst van Indonesië te betrekken dat dit niet zou mogen afstuiten op het verwerpen van termen als 'Republikeinse regering' en dergelijke. Anderhalve maand later bleek Beel zijn mening te hebben herzien: op 26 februari richtte hij een brief aan 'de president van de Republiek Indonesia', waarin hij Soekarno uitnodigde op korte termijn een delegatie te vormen voor overleg met Nederland en de BFO.

Er was intussen van alles gebeurd. Op 28 januari had de Veiligheidsraad de resolutie aangenomen waarin hij de CGD omzette in de van grotere bevoegdheden voorziene United Nations Commission for Indonesia (UNCI) en waarin hij Nederland niet alleen opnieuw opriep om de geïnterneerde Republikeinse leiders vrij te laten, maar ook om hen naar Jogja te laten terugkeren. Tot dit laatste was de Nederlandse regering volstrekt niet bereid, maar Soekarno en Agoes Salim kregen wel toestemming zich bij de geïnterneerden op Bangka te voegen. Bij hun aankomst daar op 6 februari werden zij door een uitgelaten menigte verwelkomd. De geïnterneerden op Bangka hadden intussen van de Nederlandse autoriteiten comfortabelere huisvesting en bewegingsvrijheid binnen het eiland gekregen. Soekarno en Hatta konden nu politiek effectiever opereren omdat zij niet meer van elkaar geïsoleerd waren; ook kregen zij herhaaldelijk bezoek van Republikeinse politici uit Java. Bovendien spraken zij al op 7 februari met een contactcommissie van de BFO onder leiding van Anak Agoeng. Kort daarna ontvingen zij de UNCI. Zij waren zich dan ook goed bewust van hun sterke positie op grond van de besluiten van de BFO en de Veiligheidsraad.

De Nederlandse koerswijziging die ten grondslag lag aan Beel's brief aan Soekarno betrof niet alleen de formele opstelling tegenover de Republikeinse leiders. De regering besloot in de loop van februari tot een nieuwe politieke aanpak en wel op basis van een aanbod tot vervroegde overdracht van de Nederlandse soevereiniteit aan Indonesië. In januari had zij Van Roijen nog in de Veiligheidsraad laten verklaren dat zij hoopte de soevereiniteit voor eind 1950 te kunnen overdragen, maar nu dacht zij er over de overdracht al meteen in april of mei 1949 te doen plaatsvinden. Deze nieuwe aanpak was in eerste aanleg door Beel zelf voorgesteld en werd daarom het 'plan-Beel' genoemd. In de oorspronkelijke opzet was dit voornamelijk een optische manoeuvre om op een vlotte manier zowel van de Republiek als van de VN-bemoeienis af te komen. Het ging in die opzet namelijk niet alleen om een vervroegde maar ook om een beperkte soevereiniteitsoverdracht. Nederland zou wel op 


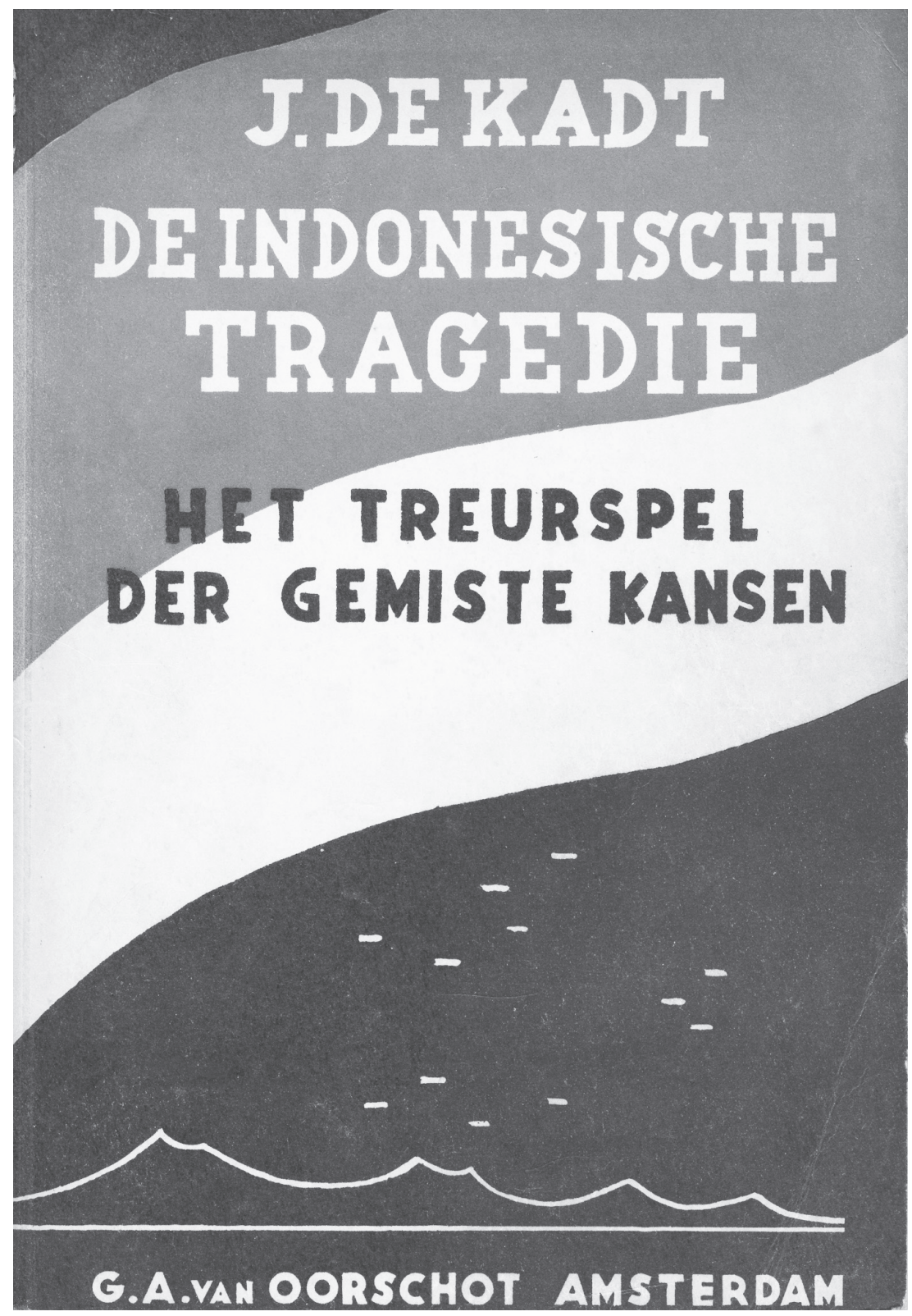

Deze felle kritiek op het Nederlandse Indonesiëbeleid werd begin 1949 gepubliceerd door de politicus Jacques de Kadt (1897-1988), die al voor de Tweede Wereldoorlog contact met Indonesische nationalisten had gehad, maar wiens pleidooien binnen de PvdA voor een ander beleid weinig steun hadden gevonden. 
korte termijn de soevereiniteit overdragen, maar daarna zou de Nederlandse Hoge Vertegenwoordiger nog een tijd lang dezelfde bijzondere bevoegdheden behouden als hem in de BIO-regeling werden toegekend. De nieuwe soevereine staat zou (naar een idee van Drees) de 'Republiek van de Verenigde Staten van Indonesië' gaan heten. De 'oude' Republiek zou alle staatsbevoegdheden die zij zich had aangemeten aan deze 'nieuwe' Republiek overdragen. Het geschil tussen Nederland en de oude Republiek zou dan niet langer bestaan en daarmee zou de reden voor de bemoeienis van de Verenigde Naties vervallen.

Beel bedoelde zijn plan in de eerste plaats als een tegenzet tegen de resolutie van de Veiligheidsraad van 28 januari. Hij legde het al eind januari aan de leiding van de $\mathrm{BFO}$ voor en besprak het midden februari persoonlijk met de regering in Den Haag. Dit leidde ertoe dat de regering het denkbeeld van een vervroegde soevereiniteitsoverdracht in aangepaste vorm overnam. De nieuwe aanpak leek een uitweg te bieden uit de problemen die in 1947 en 1948 een akkoord met de Republiek in de weg hadden gestaan. Die problemen waren immers in hoofdzaak voortgekomen uit de eisen die Nederland toen stelde met betrekking tot de overgangsperiode die aan de soevereiniteitsoverdracht vooraf zou gaan. Van Republikeinse kant was al in 1948 gevraagd of men die periode niet kon overslaan; binnen de BFO had ook Anak Agoeng dat bepleit. Nederland had daar toen echter niet van willen weten. De achtergrond hiervan was steeds geweest dat Nederland in de overgangsperiode waarborgen wilde scheppen voor het behoud van een duurzame Nederlandse invloed in Indonesië, in het bijzonder door een eind te maken aan de macht van het leger en de autonome strijdgroepen in de Republiek. Het was dan ook verrassend dat de regering nu alsnog bereid bleek van de overgangsperiode af te zien. In de oorspronkelijke opzet van het plan-Beel was dit vooral een zaak van optiek geweest: dat plan kwam in wezen neer op omkering van de volgorde tussen overgangsperiode en soevereiniteitsoverdracht, want Nederland zou na die overdracht toch nog tijdelijk een machtspositie behouden door bijzondere rechten voor zijn Hoge Vertegenwoordiger. Tijdens het overleg in Den Haag had Beel er echter mee ingestemd van het voorbehouden van zulke rechten af te zien; het ging nu dus toch om een reële soevereiniteitsoverdracht. Wel zou aan die overdracht overeenstemming moeten voorafgaan over het statuut van de Nederlands-Indonesische Unie en over tussen Nederland en Indonesië te sluiten overeenkomsten op financieel, economisch en militair gebied.

Voor de Nederlandse regering was de nieuwe aanpak vooral uit tactisch oogpunt aantrekkelijk, omdat zij met een aanbod om de soevereiniteit al op korte termijn over te dragen de Veiligheidsraad kon overtroeven die de datum van 1 juli 1950 als limiet gesteld had. Het Nederlandse publiek reageerde in het algemeen positief op het denkbeeld van een vervroegde overdracht. De opvattingen in Nederland ten aanzien van Indonesië hadden in de afgelopen jaren een grote ontwikkeling doorgemaakt. De meeste Nederlanders waren nu 
aan de gedachte gewend dat Indonesië een onafhankelijk land zou worden, hoe pijnlijk velen dit ook vonden. Aan de vraag welke plaats de Republiek daarin zou innemen hechtte men minder belang. Sinds de tweede 'politionele actie' (die men ten onrechte als een groot succes beschouwde) was men vooral geïnteresseerd in een spoedige repatriëring van de uit Nederland uitgezonden militairen.

Het feit dat de Nederlandse regering een nieuwe aanpak overwoog droeg ertoe bij dat de Veiligheidsraad besloot de kwestie-Indonesië pas in maart weer te bespreken. Tot op zekere hoogte was het ook aan de Koude Oorlog te danken dat Nederland zich voorlopig nog kon veroorloven geen volledig gevolg te geven aan de resoluties van de Raad. De Amerikaanse regering was in de eerste maanden van 1949 bezig samen met een aantal West-Europese landen een militair bondgenootschap (de latere NAVO) op te richten als tegenwicht tegen de machtsuitbreiding van de Sovjet-Unie. Omdat de Nederlandse regering hier een belangrijke rol bij speelde, kwam het Washington nu niet gelegen dat de VN dwangmaatregelen tegen Nederland zou nemen. Dit neemt niet weg dat de Amerikaanse regering in het kader van haar Aziëbeleid vertrouwen bleef stellen in Hatta en Soekarno als authentieke anticommunistische leiders en dat zij wel degelijk vond dat Nederland de VR-resolutie van 28 januari zou moeten aanvaarden.

Overigens was het overleg over het Indonesiëbeleid binnen de Nederlandse regering en tussen de regering en Beel in de loop van januari en februari met grote onenigheid gepaard gegaan. Dit leidde er onder meer toe dat minister Sassen op 14 februari ontslag nam; hij werd opgevolgd door de eveneens tot de KVP behorende minister van binnenlandse zaken, J.H. van Maarseveen. Deze verklaarde kort daarna in het parlement dat de regering haar fundamentele bezwaren handhaafde tegen verschillende delen van de VR-resolutie van 28 januari, waaronder het herstel van de Republikeinse regering in Jogja en het recht van de UNCI om met meerderheid van stemmen besluiten te nemen.

Omstreeks dezelfde tijd overwoog ook Beel ontslag te nemen, maar hij zag hiervan af omdat hij tijdens zijn overleg in Den Haag alsnog met de regering tot overeenstemming kwam. Men besloot toen zowel de federalisten als de Republikeinen uit te nodigen om in maart naar Den Haag te komen voor een Rondetafelconferentie (RTC) ter regeling van een vervroegde soevereiniteitsoverdracht. Als de Republikeinen die uitnodiging zouden afwijzen hoopte men de RTC toch te kunnen laten doorgaan. Verder besloot men de internering van de Republikeinse leiders op te heffen, maar hen niet toe te staan naar Jogja te gaan. Terwijl men de nieuwe bevoegdheden van de UNCI afwees besloot men haar wel uit te nodigen om bij de RTC 'goede diensten' te verlenen.

Na terugkeer in Batavia lichtte Beel op 26 februari zowel Soekarno als de $\mathrm{BFO}$ en de UNCI schriftelijk in over de voorgenomen RTC, die zo mogelijk 
op 12 maart zou moeten beginnen. Zijn kabinetschef Koets bracht twee dagen later een bezoek aan de Republikeinse leiders op Bangka, waarbij hij zich inspande hun wantrouwen tegen de Nederlandse bedoelingen zo veel mogelijk weg te nemen, maar ook meedeelde dat zijn regering hun terugkeer naar Jogja voorlopig niet zou toestaan. De formele opheffing van de internering betekende dus dat de Republikeinse leiders vrij waren om hetzij te gaan naar een plaats in Indonesië onder Nederlands bestuur, hetzij naar het door de Nederlandse troepen niet betreden Atjeh, hetzij naar het buitenland. Soekarno en de zijnen besloten van geen van die drie mogelijkheden gebruik te maken, maar op Bangka te blijven zo lang zij niet naar Jogja konden terugkeren. De Nederlandse regering bleef daardoor onder zo groot mogelijke druk staan om aan de resolutie van de Veiligheidsraad gevolg te geven, terwijl bij het publiek het beeld gehandhaafd bleef dat Nederland de Republikeinse leiders nog steeds gevangen hield.

Kort na het bezoek van Koets hadden Soekarno en Hatta gelegenheid het Nederlandse voorstel met invloedrijke federalisten te bespreken. Op 2 en 3 maart ontvingen zij op Bangka een delegatie van de BFO onder leiding van haar voorzitter sultan Hamid en haar vicevoorzitter Anak Agoeng. De Republikeinse voormannen zeiden geen gehoor te zullen geven aan de uitnodiging voor de RTC zolang de Republikeinse regering niet naar Jogja kon terugkeren en zolang het niet vaststond dat de UNCI de bevoegdheden zou kunnen uitoefenen die de Veiligheidsraad haar verleend had. Nadat de federalistische delegatie in Batavia teruggekeerd was vond daar een voltallige BFO-vergadering plaats. De leiders van sommige deelstaten verzetten zich hevig tegen tegemoetkomingen aan de Republiek, maar zij waren in de minderheid. Intussen werd ook het nieuws bekend over de TNI-aanval op Jogja die had aangetoond dat de Republiek militair nog geenszins verslagen was. Uiteindelijk nam men in de vroege ochtend van 4 maart eenstemmig een door Anak Agoeng voorgestelde resolutie aan waarin de BFO bepleitte dat de Nederlandse regering voldoen zou aan de door de Republikeinse leiders gestelde voorwaarden, namelijk gezagsherstel van de Republiek in Jogja en aanvaarding van de positie van de UNCI overeenkomstig de VR-resolutie van 28 januari. Beel was woedend over dit besluit, maar slaagde er niet in het ongedaan te maken. Iedere kans op een Nederlands akkoord met de federalisten buiten de Republiek om was nu voorgoed verkeken.

Eveneens op 4 maart schreef Soekarno aan Beel dat hij in beginsel met het doel van de voorgestelde Rondetafelconferentie instemde. Hij voegde hier echter aan toe dat hij in zijn huidige situatie geen besluiten kon nemen over deelname aan de RTC namens de Republiek; zulke besluiten zouden alleen genomen kunnen worden door een in Jogja gevestigde en daar volledig gezag bezittende Republikeinse regering. 


\section{Het akkoord tussen Roem en Van Roijen}

Het Nederlandse beleid had in februari 1949 een grote zwenking gemaakt door de uitnodiging aan Soekarno om een delegatie voor de RTC aan te wijzen. Daarna belandde dit beleid begin maart in een impasse omdat hij antwoordde dat alleen een in Jogja gevestigde Republikeinse regering daarover zou kunnen besluiten. Soekarno kon onmogelijk een ander standpunt innemen. Zolang de op Bangka verblijvende leiders geen toestemming kregen om naar Jogja terug te keren waren zij niet werkelijk vrij. Zouden ze onder die omstandigheden politiek overleg met Nederland voeren, dan zou hun achterban dit als verraad kunnen zien. Zij zouden een breuk riskeren met de leiders van de Republikeinse strijdkrachten en in het bijzonder met opperbevelhebber Soedirman. Formeel konden Soekarno en Hatta trouwens geen besluiten nemen die de Republiek zouden binden; de bevoegdheid daartoe hadden zij overgedragen aan de noodregering op Sumatra onder leiding van Sjafroedin Prawiranegara.

Aan de andere kant was het voor de Nederlandse regering bijzonder moeilijk om aan de wens van de Veiligheidsraad te voldoen tot herstel van de Republikeinse regering in Jogja. Uitschakeling van het Republikeinse actiecentrum was in december het hoofddoel van de tweede 'politionele actie' geweest. De Nederlandse verovering van Jogja en de gevangenneming van de Republikeinse leiders golden dan ook als de grootste successen van die actie. Het ongedaan maken van deze successen zou de indruk wekken dat de actie nergens voor gediend had. Voor een groot deel van het Nederlandse publiek was dit onbegrijpelijk; voor de leiding van de Nederlandse troepenmacht in Indonesië was het onverdraaglijk. Niettemin besloot de regering naar aanleiding van het BFO-besluit van 4 maart, waarin de federalisten het standpunt van de Republikeinse leiders ondersteunden, toch de mogelijkheid te onderzoeken om die leiders onder bepaalde voorwaarden naar Jogja te laten terugkeren. Eén van die voorwaarden zou moeten zijn dat zij hun gewapende achterban zouden opdragen de strijd te staken; verder dacht men onder meer aan een Republikeinse toezegging om aan de RTC deel te nemen en aan een regeling waarbij de Republiek in Jogja alleen burgerlijk bestuur zou uitoefenen terwijl de verantwoordelijkheid voor de handhaving van orde en veiligheid bij Nederland zou blijven berusten. Voordat de regering besloot de mogelijkheid van zo'n compromisoplossing te onderzoeken vergewiste zij zich ervan dat zij hiervoor op voldoende parlementaire steun kon rekenen. Zelfs Romme bleek zo'n oplossing niet bij voorbaat te verwerpen.

De bereidheid tot een voorwaardelijk herstel van de Republikeinse regering in Jogja betekende een drastische koerswijziging. De Nederlandse regering liet zich hierbij niet leiden door de betogen van Beel en Spoor, volgens wie de politieke en militaire situatie in Indonesië zich in voor Nederland gunstige zin 
ontwikkelde. Beel berichtte dat zich onder de bevolking van de nieuw bezette gebieden een wijdverbreid verlangen openbaarde om zich van de Republiek los te maken. Als Nederland nog een half jaar de tijd kreeg zou het volgens hem alsnog een bevredigende oplossing van het Indonesische probleem tot stand kunnen brengen. Spoor verklaarde dat de 'Soekarno-kliek' verrassend snel in het vergeetboek was geraakt. Volgens hem was de tweede 'politionele actie' geslaagd en maakte de Nederlandse legermacht nu goede vorderingen met de vierde en laatste fase van die actie, namelijk het opruimen van het nog resterende kleine verzet. Wel wees hij er op deze fase een extra grote inzet van militair personeel vergde. Hij vond daarom dat alle demobilisaties tot het eind van het jaar opgeschort moesten blijven, dat daarnaast nieuwe troepenaanvoer uit Nederland nodig was en dat troepenvermindering pas in 1951 zou kunnen plaatsvinden.

De Nederlandse regering dacht hier heel anders over. Zij wilde in ieder geval alle oorlogsvrijwilligers en de 7 December-divisie nog in 1949 gedemobiliseerd zien (volgens de oorspronkelijke toezeggingen had dat al in 1948 moeten gebeuren). Zij besefte dat Nederland niet voor onbepaalde tijd een grote troepenmacht in Indonesië op de been kon houden; het Nederlandse volk zou niet bereid zijn de daarvoor vereiste personele en materiële offers te brengen. Bovendien moest Nederland in het kader van het nieuwe Noord-Atlantische bondgenootschap een militaire bijdrage gaan leveren aan de weerbaarheid van West-Europa. Verder kon de regering rekening houden met een veranderde opstelling van één van de bestanddelen van de 'koloniale troika', namelijk de ondernemers van de westerse productiebedrijven in Indonesië (vergelijk p. 532). In 1947 hadden zij verlangd dat de regering haar militaire macht gebruiken zou om de veilige exploitatie van die bedrijven te verzekeren; sinds het decemberoffensief was de situatie van die bedrijven dramatisch verslechterd, maar nu gaven de meeste ondernemers voorkeur aan beëindiging van de strijd door een politiek akkoord.

Terwijl de Nederlandse regering dus graag overleg wilde plegen over een compromisoplossing voor de terugkeer naar Jogja van de op Bangka vertoevende Republikeinse leiders, stuitte zij op het probleem dat deze leiders het zich politiek slecht konden veroorloven aan zulk overleg deel te nemen. Dit procedureel-politieke probleem werd opgelost door de Veiligheidsraad, die van 10 maart af een reeks besprekingen aan de Indonesische kwestie wijdde. Daarin werd Nederland weliswaar van vele kanten aangevallen, maar uiteindelijk bleken de meeste VR-leden geen bezwaar te hebben tegen voorbereidend overleg tussen Nederland en de Republiek, mits dat zou plaatsvinden binnen het kader van de VR-resoluties en onder auspiciën van de UNCI. Op 23 maart legde de Raad dit vast in een procedurele richtlijn waardoor de UNCI gemachtigd werd de partijen bij te staan om overeenstemming te bereiken over de uitvoering van de resolutie van 28 januari en over de voorwaarden en 
de datum van de voorgestelde conferentie in Den Haag.

De UNCI nodigde daarop beide partijen uit om op basis van deze richtlijn overleg in Batavia te voeren. Daarbij richtte zij de voor de Republiek bestemde uitnodiging aan Mohammad Roem, sinds 1948 voorzitter van de Republikeinse onderhandelingsdelegatie. Bij zijn aanvaarding van deze uitnodiging onderstreepte Roem dat het regeringsgezag van de Republiek aan de noodregering op Sumatra overgedragen was en dat hij daarom in eerste aanleg alleen zou kunnen praten over praktische aspecten van het herstel van de Republikeinse regering in Jogja.

De Nederlandse regering benoemde Van Roijen, destijds ambassadeur in Canada, tot voorzitter van haar delegatie in de door de UNCI bijeengeroepen voorbereidende conferentie. Van Roijen had de ontwikkeling van het geschil tussen Nederland en de Republiek van begin af aan meegemaakt. Als minister in het eerste naoorlogse kabinet had hij in april 1946 nog aan de conferentie op de Hoge Veluwe deelgenomen. Als vertegenwoordiger van Nederland in de Veiligheidsraad had hij het regeringsbeleid steeds trouw en bekwaam verdedigd, maar had hij ook ervaren hoe zwak Nederlands internationale positie was. In zijn nieuwe functie kwam hij op 12 april in Batavia aan. Tijdens zijn verblijf in Indonesië vormde hij zich een eigen oordeel over de politieke en militaire situatie en stelde hij zich kritisch op tegenover de door Spoor en Beel gegeven voorstelling van zaken.

De voorbereidende conferentie vond plaats in Hotel des Indes in Batavia en werd op 14 april geopend door Cochran, die ook verder in het overleg een actieve rol bleef spelen. Rekening houdend met de opstelling van Roem bespraken de delegaties in de volgende weken allereerst de kwestie van de terugkeer van de Republikeinse regering naar Jogja. Van Roijen had echter uitdrukkelijk instructie zich op dit punt niet te binden voordat men het in beginsel ook eens geworden was over twee andere onderwerpen: de beëindiging van de vijandelijkheden en de deelname aan de RTC. Behalve met Roem en diens delegatie voerde Van Roijen ook overleg met Hatta, die daartoe uit Bangka overkwam, en met de sultan van Jogja. Hij begon in tijdnood te raken omdat de Algemene Vergadering van de Verenigde Naties op 10 mei weer bijeen zou komen; Nederland zou daar in de beklaagdenbank terechtkomen als het overleg in Batavia dan nog geen resultaat geboekt had. Het lukte de delegaties echter tijdig beginselovereenstemming over alle drie onderwerpen te bereiken, waarna men dit op 7 mei in twee mondelinge verklaringen vastlegde.

Als eerste sprak Roem, die verklaarde dat Soekarno en Hatta hem gemachtigd hadden om hun persoonlijke verzekering te geven dat zij voorstander waren van:

1. het uitvaardigen van een bevel aan de gewapende aanhangers van de Republiek om de guerrilla-oorlog te staken; 
2. samenwerking gericht op het herstel van de vrede en het handhaven van orde en recht;

3. deelname aan een Rondetafelconferentie in Den Haag teneinde de onvoorwaardelijke overdracht van werkelijke en volledige soevereiniteit aan de Verenigde Staten van Indonesië te bespoedigen,

en dat zij zich verbonden sterk te zullen aandringen op aanvaarding van deze punten door de regering van de Republiek wanneer die weer in Jogja zou zetelen.

Hierna sprak Van Roijen een uit zeven punten bestaande verklaring uit. Die hield in de eerste plaats in dat zijn delegatie gemachtigd was in te stemmen met de terugkeer van de Republikeinse regering naar Jogja, waar zij vrij zou zijn om de haar toekomende functies uit te oefenen. Onder auspiciën van de UNCI zou men nader overleg plegen over de nodige voorbereidingen daartoe en over maatregelen om staking van de guerrillastrijd, herstel van de vrede en handhaving van orde en recht te verwezenlijken. Een ander punt van de verklaring was dat de Nederlandse regering geen nieuwe deelstaten of autonome gebieden zou instellen of erkennen binnen het gebied dat voor 19 december 1948 onder Republikeins gezag stond. Wat het doel van de RTC betreft bevestigde de verklaring dat het ging om onvoorwaardelijke overdracht van werkelijke en volledige soevereiniteit.

De twee op 7 mei door Roem en Van Roijen uitgesproken verklaringen vormden tezamen een akkoord dat de weg opende naar een politieke oplossing van het geschil tussen Nederland en de Republiek. Hierbij verdient het de aandacht dat Van Roijen's verklaring het functioneren van de Republikeinse regering in het over te dragen gebied niet beperkte tot de uitoefening van alleen burgerlijk bestuur, zodat die regering daar dus ook verantwoordelijk zou worden voor de handhaving van orde en veiligheid. Voordat de Nederlandse regering haar delegatie machtigde dit akkoord aan te gaan hadden Beel en Spoor zich er krachtig tegen verzet. Beel had onder meer willen vasthouden aan de vorming van nieuwe deelstaten op Republikeins gebied en had aan de Republikeinse regering op zijn hoogst een puur symbolische terugkeer naar Jogja willen toestaan. Omdat de regering de machtiging toch verleende nam hij ontslag als Hoge Vertegenwoordiger van de Kroon. Tot zijn opvolger benoemde de regering A.H.J. Lovink, destijds secretaris-generaal van het departement van buitenlandse zaken. Lovink, die voor de oorlog een hoge ambtenaar van het Nederlands-Indisch gouvernement in Batavia geweest was en later belangrijke ambassadeursposten bekleed had, was door zijn werk op het departement goed op de hoogte van de Indonesische kwestie en de internationale aspecten ervan. Hij trad op 2 juni aan als de nieuwe HVK.

Hoewel het akkoord van 7 mei in feite het failliet bezegelde van het door Spoor voorgestane beleid, besloot deze geen ontslag te nemen omdat hij zijn soldaten niet in de steek wilde laten. Intussen bleef hij ervan overtuigd dat hij 
met betrekking tot de militaire en politieke situatie in Indonesië geen enkele beoordelingsfout gemaakt had; de schuld voor wat er misgegaan was legde hij alleen bij de politici. Tot ieders verrassing verdween echter ook Spoor van het toneel omdat hij op 25 mei als gevolg van een hartaanval overleed. Zijn chef-staf, Buurman van Vreeden, werd door de regering tot zijn opvolger benoemd.

Het Nederlandse publiek reageerde gemengd op het tussen Van Roijen en Roem gesloten akkoord. Aan de ene kant was men opgelucht door het vooruitzicht op een vreedzame oplossing van het conflict in Indonesië; aan de andere kant was men geschokt dat de regering ondanks de klinkende overwinning op de Republiek nu toch Soekarno en Hatta naar Jogja wilde laten terugkeren; men kon dit alleen begrijpen als zwichten voor buitenlandse druk. Dat Nederland ook in Indonesië zelf onder druk stond, omdat zijn troepen steeds minder opgewassen waren tegen de Republikeinse guerrilla-oorlog, was bij het Nederlandse publiek in het geheel niet bekend. Overigens leidde het akkoord in Nederland niet tot grootscheeps protest zoals eind 1946 na het akkoord van Linggadjati gerezen was. Het conflict had nu al bijna vier jaar geduurd en de meeste Nederlanders waren het moe. Minister Van Maarseveen, die nog in februari in het parlement verklaard had dat zijn regering fundamenteel bezwaar had tegen terugkeer van de Republikeinse leiders naar Jogja, zei dat het nu om een andere zaak ging omdat deze leiders hun medewerking toegezegd hadden om aan de guerrilla-oorlog een eind te maken.

Aan Republikeinse kant stuitte het akkoord bij velen op wantrouwen en teleurstelling. Sjafroedin Prawiranegara, leider van de volledig gepasseerde noodregering op Sumatra, vond de toegezegde terugkeer naar Jogja een veel te kleine Nederlandse concessie tegenover de Republikeinse toezegging om de strijd te staken. Aan de andere kant wilde hij Soekarno en Hatta niet openlijk afvallen, want dat zou de positie van de Republiek alleen maar schaden. Hetzelfde gold voor Soedirman, die vond dat Soekarno en Hatta helemaal niet hadden moeten onderhandelen. Om meer begrip voor het akkoord te wekken bracht Hatta begin juni een bezoek aan Sumatra. Op Java besloten de partijbesturen van de Masjoemi en de PNI (de partijen van Roem en Ali Sastroamidjojo) het akkoord te steunen. De door volgelingen van Tan Malaka geleide linkse oppositie wees het akkoord af.

Het op 7 mei gesloten akkoord legde slechts een beginselovereenstemming vast die in overleg tussen de delegaties nader uitgewerkt moest worden. Daartoe stelde de voorbereidende conferentie twee subcommissies in. Eén hiervan bereidde de terugkeer naar Jogja voor; de sultan van Jogja leidde zelf de Republikeinse delegatie in dit orgaan. De andere subcommissie besprak de regeling van het staakt-het-vuren en het herstel van de vrede; de Republikeinse delegatie stond hier onder leiding van minister Leimena, die ook delegatieleider geweest was bij het overleg over militaire zaken na het Renville-akkoord. 
Het overleg tot uitwerking van het akkoord van 7 mei nam onverwacht veel tijd in beslag. In juni kreeg ook de BFO gelegenheid aan de voorbereidende conferentie deel te nemen. Op 22 juni nam zij met een delegatie onder sultan Hamid en Anak Agoeng voor het eerst aan een formele zitting deel. Van Roijen deelde in deze zitting mee dat de terugtrekking van de Nederlandse troepen uit Jogja op 24 juni zou beginnen en dat de Republikeinse regering daar een week later zou kunnen terugkeren. Verder verklaarden de delegaties overeenstemming bereikt te hebben over het programma voor de Rondetafelconferentie en over het staken van de vijandelijkheden.

Men kon het overleg over deze laatste kwestie echter pas voltooien nadat de regering van de Republiek zich weer in Jogja gevestigd had. Daarna werd de regeling voor het staken van de vijandelijkheden op 1 augustus formeel vastgesteld in een slotvergadering van de voorbereidende conferentie.

\section{Terugkeer van Soekarno en Hatta in Jogjakarta}

De op 28 januari 1949 door de Veiligheidsraad aangenomen resolutie had onder meer van Nederland verlangd, dat het de gevangen genomen Republikeinse leiders in de gelegenheid zou stellen terug te keren naar Jogjakarta en daar het bestuur uit te oefenen in de stad en haar onmiddellijke omgeving. In het op 7 mei tussen Roem en Van Roijen gesloten akkoord was echter overeengekomen dat het Republikeinse bestuur een groter gebied zou bestrijken, namelijk de hele 'residentie' Jogjakarta, een bestuursdistrict dat in feite samenviel met het grondgebied van het sultanaat Jogjakarta.

Bij het uitwerken van een regeling voor de overdracht van het gebied konden de onderhandelaars profijt trekken van het feit dat de sultan van Jogja, Hamengkoe Boewono IX, zowel in het koloniale als in het Republikeinse bestel een eigen plaats innam: als sultan werd hij door Nederland erkend, maar tegelijk maakte hij als minister zonder portefeuille deel uit van de regering van de Republiek. Men belastte hem nu met de verantwoordelijkheid voor de veiligheid in het gebied tijdens de overgangsfase. Daartoe kreeg hij onder meer de beschikking over een speciale politiemacht die gedeeltelijk door Nederland van wapens en vervoermiddelen voorzien werd.

Overigens was het akkoord van 7 mei aanleiding voor een uittocht van inwoners van het gebied die vreesden onder Republikeins bestuur niet meer veilig te zullen zijn. Nederlandse radiouitzendingen hadden die vrees sterk aangewakkerd. Deze uittocht, die zich eind mei en begin juni voltrok, betrof ruim veertigduizend personen, in hoofdzaak Chinese handelaren met hun gezinnen en Indonesiërs die nauw met het Nederlandse gezag samengewerkt hadden.

Op 23 juni vaardigde de sultan een dagorder uit waarin hij de Republikeinse 
militairen opdroeg zich van vijandelijkheden te onthouden tijdens de ontruiming van het gebied door de Nederlandse troepen. Zoals Van Roijen al aangekondigd had begon die ontruiming op 24 juni. Op 30 juni vertrokken de laatste Nederlandse soldaten, waarna de sultan de verantwoordelijkheid overnam. TNI-eenheden die aan de guerrilla-oorlog in het gebied deelgenomen hadden trokken Jogja binnen.

De weg was nu vrij voor de terugkeer van Soekarno en Hatta. Op 6 juli bracht een vliegtuig van de Verenigde Naties hen en de andere leiders uit Bangka terug. Hun intocht in Jogja werd een triomftocht.

Het was eerst nog onzeker of opperbevelhebber Soedirman bereid zou zijn zich weer onder Soekarno's gezag te schikken. Tot veler opluchting keerde hij op 10 juli in Jogja terug. Hij bracht daar eerst een bezoek aan Soekarno en Hatta en nam vervolgens een parade van Republikeinse soldaten af, niet gekleed in zijn generaalsuniform maar in sarong, trui en de legerjas die hij tijdens zijn omzwervingen in de afgelopen maanden gedragen had. Op dezelfde dag kwam het hoofd van de noodregering, Sjafroedin Prawiranegara, uit Sumatra aan.

Op 13 juli vond een zitting van het Republikeinse kabinet plaats waarin de uit Bangka teruggekeerde leiders voor het eerst bijeenkwamen met de leiding van de noodregering en van haar commissariaat op Java (van de vijf ministers die dit commissariaat gevormd hadden was intussen één gesneuveld). Nadat de noodregering en haar commissariaat verslag hadden uitgebracht over hun optreden, gaf Sjafroedin het mandaat van de noodregering terug. Het volledig herstel van de regering van de Republiek was hiermee een feit. Deze regering aanvaardde vervolgens de beleidspunten die vervat waren in de verklaring van Roem van 7 mei en waarvoor Soekarno en Hatta beloofd hadden zich sterk te zullen maken: staking van de guerrillastrijd en deelname aan de Rondetafelconferentie in Den Haag. Enige dagen later verwierf het nieuwe beleid ook steun van een meerderheid in het Werkcomité van het KNIP. Om het draagvlak voor dit beleid te versterken wijzigde Hatta de samenstelling van zijn regering. Onder meer werd de sultan van Jogja, die tot nu toe minister zonder portefeuille geweest was, minister van defensie in het nieuwe kabinet.

Het herstel van de Republikeinse regering in Jogja kreeg in het buitenland een gunstig onthaal als bewijs van een ommekeer in het Nederlandse beleid. Het leidde onder meer tot intrekking van de door verscheidene Aziatische landen aan Nederland opgelegde verboden om van hun vliegvelden gebruik te maken.

De na 7 mei onder inwoners van het sultanaat gewekte vrees voor wraak en geweld, die tienduizenden ertoe gebracht had het gebied te verlaten, bleek ongegrond. Er vonden geen gewelddadigheden plaats, er werden geen maatregelen genomen tegen Indonesiërs die met het koloniale gezag samen- 
gewerkt hadden en Nederlanders die Jogja bezochten konden zich zelfs in verre uithoeken van de stad vertonen zonder dat hun iets overkwam. Dit bleek ook aan de Nederlandse delegatie, die op 16 en 17 juli een bezoek aan Jogja bracht. Van Roijen voerde bij deze gelegenheid gesprekken onder vier ogen met Soekarno, Hatta, de sultan van Jogja, Agoes Salim en Simatoepang.

\section{Akkoord tussen de Republiek en de federalisten}

Gedurende het hele jaar 1949 hebben de Indonesische federalisten een belangrijke politieke rol gespeeld. Daarbij sloten zij begin augustus een veelomvattend akkoord met de Republiek. Terwille van een goed begrip daarvan volgt hier eerst een terugblik op de manier waarop die rol van de federalisten zich heeft ontwikkeld.

Sinds 1946 ging het dekolonisatiebeleid van de Nederlandse regering ervan uit dat een onafhankelijk Indonesië alleen maar goed zou kunnen functioneren als het een federatie vormde. Hoe dit uitgangspunt te rijmen viel met het feit dat Nederland zelf de kolonie Nederlands-Indië altijd unitaristisch bestuurd had legde de regering niet uit. De door haar voorgestane federale opbouw van het toekomstige Indonesië kreeg steun van een in Malino bijeengeroepen conferentie van Indonesische vertegenwoordigers uit gebieden buiten Java en Sumatra. Van Mook pleitte daar voor de vorming van vier grote deelstaten, Java, Sumatra, Borneo en Oost-Indonesië. In het akkoord van Linggadjati van november 1946 aanvaardde ook de Republiek dat Indonesië een federatie worden zou; volgens dit akkoord zou die uit drie deelstaten bestaan, OostIndonesië, Borneo en de Republiek (die Java en Sumatra zou omvatten). Eind 1946 richtte Van Mook de deelstaat Oost-Indonesië op. De oprichting van een deelstaat Borneo werd uitgesteld omdat een deel van de bevolking van dat eiland sterk Republikeinsgezind was; wel werden daar enige autonome gebieden gevormd. Na het Nederlandse offensief van juli 1947 zorgde Van Mook ervoor dat (in strijd met het akkoord van Linggadjati) ook in de op de Republiek veroverde gebieden nieuwe deelstaten gevormd werden: Madoera, Oost-Java, Pasoendan (West-Java), Zuid-Sumatra en Oost-Sumatra. Zijn vroegere gedachte dat de Indonesische federatie alleen uit enkele grote eenheden zou moeten bestaan had hij laten varen.

In de loop van 1948 begon de doelstelling van het Nederlandse federaliseringsbeleid te veranderen. Overal waar Nederland nu de macht in handen had, zowel in het Malinogebied als op Java en Sumatra, had het Indonesiërs gevonden die bereid waren tot samenwerking met het Nederlandse gezag. Terwijl men de stichting van deelstaten en autonome gebieden oorspronkelijk bevorderd had om tegenwichten tegen de Republiek te vormen, dacht men nu aan de mogelijkheid hiermee een alternatief voor de Republiek op te bouwen. 
Men trof voorbereidingen voor de stichting van een Indonesische federatie zonder de Republiek. Meer en meer deed men het voorkomen alsof het bij de dekolonisatie van Indonesië niet ging om een conflict tussen Nederland en de Republiek, maar om een interne tegenstelling in Indonesië tussen de voorstanders van twee verschillende staatkundige concepties, die van de bondsstaat tegenover die van de eenheidsstaat, kortom een tegenstelling tussen federalisten en unitaristen. Daarbij behandelde men de Republiek als kampioen van de unitaire conceptie; weliswaar had zij de federale conceptie herhaaldelijk formeel onderschreven, maar zij weigerde haar eigen status tot die van een deelstaat te verlagen. Tot de echte federalisten rekende men daarentegen de leidende figuren uit de door het Nederlands-Indische gouvernement opgerichte deelstaten en autonome gebieden (de 'federale' gebieden).

De meeste van deze figuren gaven inderdaad voorkeur aan een federale opbouw van het toekomstige Indonesië, maar onderling verschilden ze sterk in hun opstelling tegenover de Republiek. Sommigen waren haar bijzonder vijandig gezind, terwijl anderen met haar sympathiseerden. Verscheidenen betreurden het dat Nederland de keuze tussen een unitair of federaal stelsel tot een keuze voor of tegen de Republiek gemaakt had. Zij wilden niet als schaakstukken gebruikt worden in een door Nederland gevoerde verdeel-enheerspolitiek. Dit onbehagen droeg medio 1948 bij tot de oprichting van een eigen overlegorgaan, de BFO, waarin de federalisten nauw gingen samenwerken als derde politieke factor naast Nederland en de Republiek.

In eerste aanleg verwelkomde de Nederlandse regering de wens van de federalisten een eigen rol te spelen. In september-oktober raadpleegde zij niet de Republiek maar wel de leiders van de BFO bij de opstelling van de regeling Bewind Indonesië in Overgangstijd (BIO). Daarentegen bekoelde de verstandhouding in november-december, omdat Nederland toen op ministersniveau overleg met de Republiek voerde maar niet bereid bleek de BFO bij dit overleg te betrekken noch haar over de resultaten ervan in te lichten. De kort daarna door Nederland tegen de Republiek ondernomen militaire actie wekte onder de federalisten verdeelde reacties. De regeringen van de twee belangrijkste deelstaten traden af. Nederland wilde nu op basis van het BIO-besluit een Indonesische interimregering instellen, maar de BFO besloot eerst met prominente Republikeinen te gaan praten voordat men aan de vorming van zo'n regering zou meewerken. Hiermee introduceerde zij een nieuw overlegkader over de toekomst van Indonesië, namelijk onderling overleg tussen de federalisten en de leiders van de Republiek.

Een en ander betekende dat de federalisten bij het politieke vervolg op de militaire actie een sleutelrol toebedeeld kregen, omdat Nederland van hun medewerking afhankelijk was om de beoogde interimregering te kunnen instellen. In deze periode verloor Nederland bij de federalisten snel aan gezag, onder meer als gevolg van de door de regering in januari 1949 aan 
de dag gelegde verwarring en besluiteloosheid. Ook de reacties binnen de Verenigde Naties droegen tot dit gezagsverlies bij; Nederland bleek internationaal alleen te staan terwijl de Republiek op internationale steun kon blijven rekenen. Het in februari door de Nederlandse regering gelanceerde aanbod tot vervroegde soevereiniteitsoverdracht maakte bovendien duidelijk dat de dekolonisatie van Indonesië nu werkelijk voor de deur stond. Na het vertrek van de Nederlanders zouden de federalisten met de Republikeinen verder moeten; daarom hadden zij nu bovenal belang bij een goede verstandhouding met de Republiek.

Anak Agoeng, premier van Oost-Indonesië en vice-voorzitter van de BFO, was zich bij uitstek van deze politieke feiten bewust en had bovendien de vindingrijkheid om op grond daarvan initiatieven te nemen. Het was op zijn voorstel dat de $\mathrm{BFO}$ in januari besloot tot overleg met de Republikeinse leiders. Het was eveneens aan hem te danken dat de BFO zich begin maart achter de voorwaarden van Soekarno en Hatta stelde voor Republikeinse deelname aan de Rondetafelconferentie (RTC) in Den Haag. Na de totstandkoming van het akkoord tussen Roem en Van Roijen in mei honoreerde de Republiek de rol van de $\mathrm{BFO}$ door ermee in te stemmen dat zij ging deelnemen aan het overleg tot uitwerking van dit akkoord. In dat kader werd op 22 juni bekendgemaakt dat de BFO-delegatie instemde met de tussen de delegaties van Nederland en de Republiek getroffen regeling over het staken van de vijandelijkheden en dat de drie delegaties het onderling eens waren geworden over de voorbereiding van de RTC.

Hierna nam Anak Agoeng een nieuw initiatief: hij stelde voor dat na het herstel van de Republikeinse regering in Jogja de BFO en de Republiek onderling overleg zouden plegen om te komen tot een gezamenlijke opstelling in de RTC. De hiertoe door hem voorgestelde Inter-Indonesische Conferentie kwam in twee zittingen bijeen, van 19 tot 23 juli in Jogja en van 31 juli tot 2 augustus in Batavia. De conferentie stond sterk in het teken van verbroedering tussen de federalisten en de Republikeinen. De ruim zestig federale afgevaardigden werden tijdens hun verblijf in Jogja met veel egards behandeld. Sommigen van hen waren verbaasd omdat hun nieuwe ervaringen sterk afweken van het overwegend negatieve beeld dat zij zich op grond van de gangbare berichtgeving over de Republiek gevormd hadden.

In de conferentie kwam een groot aantal staatkundige, militaire, financiele, economische en culturele onderwerpen aan de orde. Men kwam overeen dat de naam van de toekomstige Indonesische federatie zou luiden Republik Indonesia Serikat (RIS, Republiek der Verenigde Staten van Indonesië). Dit was van aanzienlijke symbolische betekenis, evenals de aanvaarding door de conferentie van het Indonesia Raya als nationaal volkslied en van de rood-witte vlag (die toen nog verboden was in al het door Nederland bestuurde gebied) als nationale vlag. Het overleg werd in Batavia voortgezet in het voormalige 
Volksraadgebouw. Deze tweede zitting leidde over de hele linie tot overeenstemming. Dit betrof in de eerste plaats de hoofdlijnen van de grondwet voor de toekomstige federatie en de organisatie van haar regering.

De opstelling van de Republiek hield één belangrijke concessie in, die al in de opzet van de conferentie besloten lag: naast de buiten Java, Madoera en Sumatra gevormde deelstaten en autonome gebieden aanvaardde zij als deelgenoten in de toekomstige Republiek der Verenigde Staten van Indonesië (RVI) ook alle deelstaten en autonome gebieden die in strijd met het akkoord van Linggadjati tussen het eerste en het tweede Nederlandse offensief gevormd waren op door Nederland veroverd Republikeins gebied. Als deelstaat binnen de RVI zou de Republiek alleen het gebied omvatten dat op grond van het Renville-akkoord onder Republikeins bestuur gebleven was. Verder kwam de Republiek de federalisten tegemoet op het punt van de samenstelling en de bevoegdheden van de Volksvertegenwoordiging en de Senaat. Eén derde van de leden van de Volksvertegenwoordiging zou afkomstig zijn uit de Jogjase Republiek, twee derde uit de federale gebieden.

Daarentegen sloten de meeste resultaten van de conferentie nauw bij de Republikeinse opvattingen aan. Tot die resultaten behoorde ook, dat aan de RVI niet alleen de Nederlandse soevereiniteit over Indonesië zou worden overgedragen maar ook de soevereiniteit van de Republiek (op basis van de onafhankelijkheidsverklaring van 17 augustus 1945). Dit laatste betekende dat de RVI zelf een voortzetting van de oorspronkelijke Republiek zou worden, terwijl de tot deelstaat verlaagde Jogjase Republiek zich tot het Renvillegebied zou beperken. Belangrijk waren bovendien de besluiten van de conferentie op militair gebied; ze voldeden volledig aan de 'Zes Punten' van Soedirman uit maart 1948 (zie p. 570). De strijdkrachten van de Republiek zouden de kern vormen van de krijgsmacht van de RVI, terwijl men Indonesische leden van het KNIL op nader te bepalen voorwaarden in die krijgsmacht zou kunnen opnemen. De defensie van Indonesië zou uitsluitend een zaak van de federale regering zijn; de deelstaten zouden geen eigen krijgsmacht onderhouden. Een en ander was precies het omgekeerde van wat in de Nederlandse plannen voorzien was, waarbij de TNI zou verdwijnen en het KNIL de kern van de federale krijgsmacht zou worden, met de mogelijkheid ex-leden van de TNI op individuele basis toe te laten, terwijl daarnaast de afzonderlijke deelstaten over eigen veiligheidsbataljons zouden beschikken. Vergeefs had de BFO in de conferentie voorgesteld dat de RVI zowel de TNI als het KNIL en de veiligheidsbataljons volledig zou overnemen. Verder voorzag de conferentie wel in de mogelijkheid Nederland te vragen tijdelijk marine-eenheden ter beschikking van de RVI te stellen, maar zij besloot dat de Nederlandse landstrijdkrachten de RVI volledig moesten verlaten. Dit was wel ver verwijderd van de Nederlandse plannen uit 1947 die ervan uitgingen dat Nederland in het kader van de Unie nog tenminste vijftien jaar lang eigen 
land-, lucht- en zeestrijdkrachten in Indonesië zou stationeren.

Tussen de twee zittingen van de Inter-Indonesische Conferentie vond in Makassar een plechtigheid plaats die de nieuwe verstandhouding tussen federalisten en Republikeinen onderstreepte. Kort daarvoor was Ratoelangie overleden, een nestor van de nationale beweging. In Nederland had hij al in 1914 de vereniging van Indonesische studenten voorgezeten en al in 1918 Jonkman en Van Mook leren kennen. Na terugkeer in Indonesië was hij leider van de Minahasa-bond en lid van de Volksraad geweest en had hij een nationalistisch tijdschrift uitgegeven. In augustus 1945 behoorde hij tot de oprichters van de Republiek Indonesië, die hem vervolgens tot gouverneur van Celebes benoemde. In april 1946 had het Nederlands bestuur hem in Makassar gevangen genomen; daarna was hij in Nieuw-Guinea geïnterneerd. Pas na het Renville-akkoord had hij zijn vrijheid teruggekregen; hij was toen naar Jogja gegaan waar hij adviseur werd van de Republikeinse onderhandelingsdelegatie. Na zijn overlijden bracht men zijn stoffelijk overschot op 25 juli naar Makassar over. Vergezeld door ministers uit zijn kabinet sprak Anak Agoeng daar een herdenkingsrede uit, staande naast de met rood-wit getooide baar.

\section{Het derde bestand tussen Nederland en de Republiek}

Van de drie in het akkoord tussen Roem en Van Roijen behandelde kwesties die de delegaties in de voorbereidende conferentie nader moesten uitwerken, namelijk de terugkeer van de Republikeinse regering naar Jogja, het programma voor de Rondetafelconferentie en de beëindiging van de vijandelijkheden, bleek de laatste kwestie verreweg de moeilijkste. Het zou na 7 mei nog meer dan drie maanden duren voordat het staakt-het-vuren eindelijk van kracht werd. Eén van de moeilijkheden bij de voorbereiding van het bestand was dat er sinds het decemberoffensief geen frontlijn tussen de Nederlandse en de Republikeinse troepen meer bestond: in de meeste delen van Java en Sumatra bevonden de TNI-eenheden zich tussen de Nederlandse troepeneenheden in. Een andere moeilijkheid was dat sommige invloedrijke Nederlandse militairen en politici er nog van bleven uitgaan dat Nederland sinds het decemberoffensief verantwoordelijk was voor de handhaving van de interne veiligheid op heel Java en Sumatra en daarom niet wilden aanvaarden dat die verantwoordelijkheid ook in gebieden buiten Jogja bij de TNI zou komen te liggen. Een derde moeilijkheid was dat de Republikeinse legerleiding niet aan de totstandkoming van een bestandsregeling wilde meewerken zo lang de Republikeinse regering niet in Jogja teruggekeerd was.

Hoewel de voorbereidende conferentie daarom niet kon beschikken over militair advies van Republikeinse kant, wist zij toch een veelomvattende regeling te ontwerpen voor de beëindiging van de vijandelijkheden en het herstel 
van de vrede. Hierbij stuitte Van Roijen enige malen op ernstige bezwaren, eerst bij de legerleiding in Batavia en later bij de regering in Den Haag. In zijn verschil van mening met Den Haag kreeg hij uiteindelijk steun van Lovink, de nieuwe HVK, en van Buurman van Vreeden, de nieuwe legercommandant, en tenslotte ook van minister Van Maarseveen, die medio juni een bezoek aan Indonesië bracht. Pas daarna gaf de regering toestemming de ontworpen regeling aan te gaan. Vervolgens maakten de delegaties op 22 juni bekend dat ze het over de bestandsregeling eens geworden waren (dit gebeurde in dezelfde vergadering waarin Van Roijen de terugkeer van de Republikeinse regering naar Jogja aankondigde). De inhoud van die regeling werd echter nog niet bekendgemaakt, omdat de Republikeinse legerleiding eerst gelegenheid moest krijgen daar haar oordeel over te geven.

De tussen de delegaties overeengekomen regeling vormde het derde bestand tussen Nederland en de Republiek. Het eerste bestand was op 14 oktober 1946 op Britse aandrang gesloten en vormde toen de opmaat naar het akkoord van Linggadjati; Nederland verbrak het op 20 juli 1947 door het lanceren van de eerste 'politionele actie'. Het tweede bestand was op 17 januari 1948 aan boord van de 'Renville' gesloten en legitimeerde in feite de Nederlandse veroveringen als gevolg van die actie; Nederland verbrak het op 19 december 1948 door het lanceren van de tweede 'politionele actie'.

De nieuwe bestandsovereenkomst bestond uit vier delen. Het eerste deel bevatte de tekst van de door de Nederlandse regering en de Republikeinse regering uit te vaardigen orders tot staking van de vijandelijkheden. Het tweede deel bevatte een door de beide regeringen gezamenlijk af te kondigen proclamatie. Daarin stond onder meer, dat iedereen zich moest onthouden van daden van vergelding of wraak, dat niemand vervolgd zou worden omdat hij in het geschil tussen Nederland en de Republiek partij gekozen had, dat politieke gevangenen in vrijheid gesteld zouden worden en dat zij die vervolgd of veroordeeld waren voor misdaden die duidelijk een uitvloeisel van het politieke conflict waren zouden worden ontslagen van verdere vervolging of worden ontheven van hun straf. Het belangrijkste bestanddeel van de overeenkomst was het derde deel, dat richtlijnen bevatte voor de uitvoering van het staken der vijandelijkheden. Het bepaalde dat de partijen in onderling overleg een afbakening en toewijzing tot stand zouden brengen van patrouillegebieden voor de handhaving van rust en orde. Die patrouillegebieden zouden overeen moeten komen met de bestuurlijke indeling. De strijdkrachten van de partijen zouden hun patrouillegebieden niet mogen uitbreiden, noch op andere manier mogen proberen hun militaire positie ten koste van de andere partij te verbeteren. De uitvoering van deze richtlijnen zou worden gedirigeerd door een centrale gemengde commissie, bestaande uit vertegenwoordigers van de UNCI, Nederland, de Republiek en de BFO; zij zou ook plaatselijke gemengde commissies kunnen instellen. Het vierde deel 
van de overeenkomst was een handboek met aanvullende bepalingen over de uitvoering van het staakt-het-vuren, de proclamatie en de richtlijnen; de tekst hiervan was op 22 juni nog niet gereed.

Na 22 juni moesten verdere stappen tot uitvoering van het bestand wachten op instemming van de Republikeinse legerleiding met de opgestelde documenten. Een week na het herstel van de Republikeinse regering in Jogja werd die instemming op alle hoofdpunten verkregen tijdens een gezamenlijke vergadering van de militaire en de politieke top van de Republiek in het ziekenhuis waar generaal Soedirman verpleegd werd. In aansluiting op die bespreking kwamen de delegaties van Nederland en de Republiek nog enige ondergeschikte wijzigingen overeen en stelden zij de tekst vast van het handboek met aanvullende bepalingen. Daarna formaliseerden ze de bestandsovereenkomst op 1 augustus in een slotvergadering van de voorbereidende conferentie. Twee dagen later vaardigden de beide regeringen hun orders tot staking van de vijandelijkheden en hun gezamenlijke proclamatie uit. Het staakt-het-vuren zou op Java op 11 augustus en op Sumatra op 15 augustus ingaan.

Hoe gewenst het was dat er een eind kwam aan het oorlogsgeweld tussen Nederland en de Republiek werd onderstreept door een incident dat juist in deze dagen plaatsvond en dat bekend geworden is als de 'bloedbruiloft van Tjilatjap'. In de avond van 1 augustus begaf een Nederlandse patrouille zich nabij Tjilatjap op weg om TNI-militairen op te sporen die zich volgens verkregen inlichtingen in een bepaald huis zouden bevinden. Bij het huis aangekomen troffen zij een menigte van enkele honderden mannen, vrouwen en kinderen aan die daar een bruiloftsfeest vierden en naar een wajangvoorstelling met gamelanmuziek keken. Bij vergissing openden enkele Nederlandse militairen het vuur op deze menigte, onder meer met een machinegeweer. Daarbij kwamen zesentwintig personen om het leven en werden drieëndertig gewond.

Bij de afkondiging van het bestand hield zowel Lovink als Soekarno een radiorede. Lovink vroeg de Nederlandse militairen te begrijpen dat ook de TNI-militairen het in de afgelopen periode niet gemakkelijk hadden gehad, dat zij vaak onder moeilijke omstandigheden en met slechte wapens en uitrusting hadden moeten vechten, maar dat zij als geheel trouw waren gebleven aan de roeping van hun vaderland zoals zij die verstonden. Ook generaal Buurman van Vreeden richtte zich tot zijn soldaten en riep hen op voortaan niet tegen maar met de TNI te strijden.

Daar men mocht aannemen dat de toewijzing van de patrouillegebieden zou plaatsvinden op grond van de situatie bij het ingaan van het staakt-hetvuren, was het niet verrassend dat beide partijen in de daaraan voorafgaande dagen hier en daar probeerden hun posities te verbeteren. Op 7 augustus ondernam de TNI zelfs een poging de stad Solo te veroveren; het Nederlandse garnizoen moest luchtsteun inroepen om de aanval af te slaan. Formeel was 
deze TNI-actie niet ongeoorloofd; het nieuwe bestand gold immers nog niet en aan het vorige bestand was niet door de Republiek maar door Nederland een eind gemaakt. Niettemin was Lovink over deze aanval en enkele andere incidenten zo verontwaardigd, dat hij besloot sommige stappen die hij in samenhang met het bestand had willen nemen enige weken uit te stellen. Hiertoe behoorden de teruggave aan de Republiek van het pand Pegangsaän Oost 56 (dat voor de Republikeinen als nationaal heiligdom gold), de opheffing van het verbod op de rood-witte vlag en het toestaan van openbare herdenking van de uitroeping van de onafhankelijkheid. Het niet toestaan van zulke herdenkingen had het door Lovink niet beoogde gevolg dat op 17 augustus ongeveer vijftigduizend personen in Batavia samendrongen rondom het kantoor van de Republikeinse delegatie aan het Koningsplein, waar een viering in besloten kring zou plaatsvinden. Het vlagverbod werd op 23 augustus opgeheven; drie dagen later vond de teruggave van Pegangsaän Oost 56 plaats.

De in de gezamenlijke proclamatie van 3 augustus vervatte oproep om zich te onthouden van daden van wraak of vergelding was vooral op Nederlandse aandrang opgenomen, ter bescherming van Indonesiërs die nauw met het Nederlandse gezag samengewerkt hadden, maar deze oproep gold uiteraard voor beide partijen. Op dit punt gaf Lovink's gouvernement zelf een slecht voorbeeld. In een gevangenis op Java bevond zich ten tijde van het staakthet-vuren Wolter Monginsidi, de jonge Menadonees die in 1946 het antiNederlandse verzet in Makassar geleid had (zie p. 516-9). Hij was sindsdien gevangen genomen, berecht en ter dood veroordeeld. Ondanks de proclamatie werd dit vonnis op 5 september alsnog voltrokken, tot bittere teleurstelling en verontwaardiging aan Republikeinse kant. De begrafenis van zijn stoffelijk overschot in Makassar groeide uit tot een massademonstratie.

Bij de uitvoering van de bestandsovereenkomst viel een belangrijke rol toe aan de Haagse ambtenaar H.L. s'Jacob. Hij was in Nederland secretarisgeneraal van het departement van financiën, maar had al in 1947-1948 enige tijd deelgenomen aan het overleg met de Republiek en was in april 1949 aan Van Roijen toegevoegd om die te assisteren bij zijn onderhandelingen met Roem. Onder meer had hij het overleg met de sultan van Jogja gevoerd over de terugkeer van Soekarno en Hatta naar de Republikeinse hoofdstad. Nadat Van Roijen begin augustus naar Nederland was vertrokken om deel te nemen aan de Rondetafelconferentie, volgde s'Jacob hem op als leider van de Nederlandse onderhandelingsdelegatie in Batavia.

In het kader van de uitvoering van de bestandsovereenkomst stelde de gemengde commissie eind augustus ook subcommissies over bepaalde onderwerpen in, onder meer over de bevoorrading van de patrouillegebieden van de TNI en over de vrijlating van gevangenen. Intussen kwam de afbakening en toewijzing van patrouillegebieden slechts moeizaam op gang, onder meer omdat de plaatselijke TNI-commandanten nog niet over de daarvoor opge- 
stelde richtlijnen beschikten. Wel vertoonden Republikeinse militairen zich nu op tal van plaatsen die naar Nederlandse mening ten tijde van het staakthet-vuren in Nederlandse handen geweest waren. Van Nederlandse kant beschouwde men dit als ongeoorloofde pogingen tot gebiedsuitbreiding, maar van Republikeinse kant stelde men telkens dat die militairen daar ongezien al voor die tijd aanwezig geweest waren. Deze controverses bemoeilijkten de toewijzing van patrouillegebieden des te meer, omdat toewijzing aan de TNI meestal ook meebracht dat die gebieden onder Republikeins bestuur kwamen te staan. Een en ander leidde tot aanzienlijke spanningen, vooral omdat veel Nederlandse officieren en ambtenaren het nog steeds als een ernstig verlies beschouwden om gebieden 'aan de vijand prijs te geven'.

Geleidelijk drong echter het besef door dat men zich van het verleden los moest maken. Omdat Nederland over enkele maanden de soevereiniteit zou overdragen had het er zelf belang bij, dat die overdracht zou geschieden aan een gezag dat over een betrouwbaar machtsapparaat beschikte. Zou dit niet het geval zijn, dan viel onder meer te vrezen dat Indonesië toch nog in de greep van het communisme zou raken. Omdat de TNI nu eenmaal de ruggegraat van het machtsapparaat van de RVI zou vormen, had Nederland dus belang bij een sterke positie van de TNI. Om chaos bij de soevereiniteitsoverdracht te voorkomen was het bovendien belangrijk dat de machts- en bestuursovergang zich niet abrupt zou voltrekken. Deze inzichten leidden tot een veranderende Nederlandse opstelling bij de uitvoering van de bestandsovereenkomst. In het bijzonder s'Jacob was zich bij uitstek bewust van het Nederlandse belang bij een solide positie van de Republiek.

De bestandsovereenkomst ging weliswaar uit van de status quo, maar verplichtte niet tot strikte handhaving daarvan, zoals al bleek uit de richtlijn om bij de afbakening de bestuurlijke indeling te volgen. De overeenkomst liet ruimte om in onderling overleg patrouillegebieden te ruilen of samen te voegen en ook om afspraken over gezamenlijke patrouillering te maken. De Nederlandse legerleiding had haar plaatselijke commandanten al gemachtigd afgelegen posten op te heffen om beter beheersbare gebieden te vormen. Intussen moest die legerleiding er ook rekening mee houden dat zij over steeds minder soldaten beschikte omdat de repatriëring van de uit Nederland uitgezonden militairen nu in volle gang was. Onder meer was de 7 December-divisie na augustus niet meer voor militaire taken beschikbaar omdat zij zich op haar verscheping naar Nederland voorbereidde. Verkleining van het door Nederlandse troepen bezette gebied was dringend gewenst. Men ging de uitvoering van de bestandsovereenkomst dan ook benutten om delen van de tijdens het decemberoffensief bezette gebieden op een onopvallende manier aan de Republiek terug te geven. In plaats van de veroveringen te legitimeren had het nieuwe bestand de mogelijkheid geopend die veroveringen ongedaan te maken.

Op Java begonnen de Nederlandse troepen in oktober zich terug te trekken 
uit de in december 1948 bezette gebieden, niet alleen uit de landelijke gebieden maar ook uit de steden. Begin november ontruimden ze Solo en Madioen, die na Jogja de twee grootste steden van de Republiek waren. Na de sluiting van de RTC ging de legerleiding over tot een nog veel verder gaande terugtrekking en concentratie van de Nederlandse strijdkrachten op Java en Sumatra, vooruitlopend op hun vertrek na de soevereiniteitsoverdracht.

De uitvoering van de bestandsovereenkomst betrof ook samenwerking op andere terreinen dan de verdeling van patrouillegebieden. Zo bepaalde de overeenkomst dat het Nederlands-Indische gouvernement desgevraagd hulp zou bieden bij de bevoorrading van de bevolking in de aan de TNI toegewezen gebieden, onder meer met voedsel, textiel en medicijnen. In aansluiting hierop kwam men overeen van Nederlandse kant ook bij te dragen aan de bevoorrading en de bezoldiging van de Republikeinse militairen zelf. Sinds het decemberoffensief waren deze militairen gedwongen geweest zich door de plaatselijke bevolking te laten onderhouden, wat zowel voor die bevolking als voor de militairen overlast en gebrek meebracht. De verantwoordelijkheid voor deze toestand lag bij Nederland, omdat het Nederlandse offensief het de Republikeinse regering en legerleiding onmogelijk gemaakt had de eigen militairen te blijven bevoorraden en bezoldigen. Om de TNI-eenheden in staat te stellen aan hun soldaten soldij te betalen ging het gouvernement er in oktober toe over hiervoor geldmiddelen te verschaffen op de voet van drie gulden per soldaat per dag. Ook stelde men van Nederlandse kant voedsel, kleding, verbindingsmiddelen en vervoermiddelen ter beschikking van de TNI. Men deed dit niet alleen om de druk op de bevolking te verlichten, maar ook om de Republikeinse militairen beter in staat te stellen zich te kwijten van de taken die nu en in de naaste toekomst op hen rustten. In dat verband hechtte Lovink's gouvernement er bijvoorbeeld belang aan, deze militairen op ruime schaal van nieuwe uniformen te voorzien. Na de sluiting van de RTC breidde men de Nederlandse bevoorrading van de Republikeinse strijdkrachten en politie verder uit, onder meer met vrachtauto's en motorfietsen en soms ook met wapens.

Deze in september-december 1949 van Nederlandse kant gedane verstrekkingen in geld en goederen konden een bevoordeling van de Republiek ten koste van Nederland lijken, maar waren het in feite niet. Al deze verstrekkingen belastten immers het budget van het Nederlands-Indische gouvernement, dat na de soevereiniteitsoverdracht het budget van de RVI worden zou.

Een heel ander onderwerp van overleg in het kader van de beëindiging van de vijandelijkheden was de vrijlating van gevangenen. Van Nederlandse kant werden in de periode september-december ongeveer dertienduizend krijgsgevangenen en politieke gevangenen in vrijheid gesteld. De vrijlatingen aan Republikeinse kant waren minder omvangrijk; het ging hierbij vooral om Indonesiërs die in de loop van het jaar ontvoerd waren. 


\section{De Rondetafelconferentie in Den Haag}

Nadat de BFO in juni 1949 gelegenheid gekregen had deel te nemen aan de voorbereidende conferentie die onder leiding van de UNCI in Batavia plaatsvond, werden de delegaties van Nederland, de Republiek en de BFO het al spoedig eens over de tijd en de voorwaarden van de in Den Haag te houden Rondetafelconferentie (RTC). Deze overeenkomst werd geformaliseerd in de vergadering van 22 juni, waarbij Van Roijen bekend maakte dat zijn regering ermee instemde.

De overeenkomst omschreef het doel van de RTC als het verkrijgen van overeenstemming over overdracht van de werkelijke, volledige en onvoorwaardelijke soevereiniteit aan de Verenigde Staten van Indonesië (VSI) in overeenstemming met de Renvillebeginselen. Zij bevatte enige procedureregels voor de conferentie en noemde een aantal kwesties die men in Den Haag zou moeten bespreken. Wat die kwesties betreft bevatte de overeenkomst nu al verschillende inhoudelijke bepalingen, onder meer over de constitutie van de VSI en over de Nederlands-Indonesische Unie. Zo bepaalde zij dat het hoogste gezag over de buitenlandse betrekkingen van de VSI en over de federale strijdkrachten uitsluitend bij de regering van de VSI zou berusten. De Unie zou geen superstaat zijn en zou over geen andere rechten beschikken dan die de deelgenoten haar vrijwillig zouden overdragen. Verder bepaalde de overeenkomst dat de UNCI aan de RTC zou deelnemen in overeenstemming met haar door de Veiligheidsraad vastgestelde mandaat en dat zij vervolgens in Indonesië zou toezien op de nakoming van de op de conferentie bereikte overeenkomsten.

Door met deze in Batavia tot stand gekomen overeenkomst in te stemmen had minister Van Maarseveen impliciet al een streep gehaald door sommige aan Nederlandse kant levende denkbeelden over de toekomstige verhouding met Indonesië. Zo was Romme, de leider van de Katholieke Volkspartij (KVP), er steeds op uit geweest van de Unie een superstaat te maken die in verschillende opzichten de rol van het Koninkrijk zou overnemen. Ook Jonkman, lid van de Partij van de Arbeid (PvdA) en van 1946 tot 1948 minister van overzeese gebiedsdelen, had de Unie als een staatsverband gezien waarbinnen bijvoorbeeld eenheid van buitenlands beleid zou moeten bestaan. Verder waren de Nederlandse beleidsmakers er lange tijd van uitgegaan dat Nederland na de soevereiniteitsoverdracht nog tenminste vijftien jaar in het kader van de Unie voor de externe verdediging van Indonesië zou zorgen. Tenslotte volgde uit de nu overeengekomen bepalingen over de UNCI dat Nederland zich niet meer verzette tegen de uitgebreide bevoegdheden die de Veiligheidsraad aan die commissie verleend had.

Wat het tijdschema voor de RTC betreft was men in Batavia overeengekomen ernaar te streven dat de conferentie tegen 1 augustus zou beginnen en tegen 1 oktober zou eindigen. Daarna zouden Nederland, de Republiek en de 
BFO de resultaten van de conferentie binnen zes weken moeten bekrachtigen; de soevereiniteit zou voor eind 1949 moeten worden overgedragen. Omdat er echter veel tijd verstreek voor de afkondiging van het staakt-het-vuren, bleek enig uitstel onvermijdelijk. Na die afkondiging op 3 augustus konden de delegaties eindelijk naar Den Haag vertrekken. Eveneens op 3 augustus zond Van Maarseveen een nota aan het parlement over de resultaten van de voorbereidende conferentie in Batavia. Op 16 en 17 augustus vond daarover een debat in de Tweede Kamer plaats. Vervolgens werd de RTC op 23 augustus geopend; men ging ervan uit dat die ruim twee maanden zou duren.

Het was een omvangrijke conferentie. De delegaties van Nederland, de Republiek, de BFO en de UNCI telden samen ongeveer honderdvijftig leden, nog afgezien van hun talrijke stafleden en adviseurs. Van Maarseveen leidde de Nederlandse delegatie, met Stikker en Van Roijen als plaatsvervangers. Met het oog op het verkrijgen van zo breed mogelijke politieke steun voor het resultaat van de RTC waren aan deze delegatie negen parlementsleden toegevoegd, onder wie zowel Jonkman, Logemann en Romme als vertegenwoordigers van partijen ter rechterzijde van PvdA en KVP. De Republikeinse delegatie stond onder leiding van Hatta, met Roem als plaatsvervanger. Verder behoorden tot deze delegatie onder meer Leimena, Ali Sastroamidjojo, Simatoepang, Soekiman en Soepomo, maar ook Abikoesno en Yamin, twee politici die zich in het verleden tegen het diplomasi-beleid van Hatta en Soekarno gekeerd hadden. De BFO-delegatie was de grootste van allemaal en had sultan Hamid als voorzitter en Anak Agoeng als eerste ondervoorzitter. Voorzitter van de RTC zelf was Drees, terwijl Van Maarseveen, Hatta en sultan Hamid als vicevoorzitters ervan optraden.

Overigens kwam de conferentie alleen bij de opening en de sluiting plenair bijeen; alle belangrijke onderhandelingen speelden zich in commissies, subcommissies en werkgroepen af. Men besprak een groot aantal staatkundige, juridische, militaire, financiële en economische onderwerpen. De UNCI spande zich keer op keer in om de tijdens de conferentie rijzende tegenstellingen te overbruggen. De RTC duurde langer dan voorzien, maar uiteindelijk werden de delegaties het over bijna alle kwesties eens; men legde dit vast in een reeks afzonderlijke overeenkomsten en briefwisselingen, samen ongeveer honderd pagina's. Alle teksten werden zowel in het Nederlands als in het Indonesisch gesteld, terwijl daarnaast een officiële Engelse vertaling gemaakt werd die in geval van verschil de doorslag zou geven.

De delegaties van de Republiek en van de BFO traden vaak gezamenlijk op. Dit gold onder meer voor de voorlopige grondwet van de RVI. De overeenkomst van 22 juni bevatte daar enkele bepalingen over, maar verder was dit geen zaak meer voor onderhandelingen met Nederland. De delegaties van de Republiek en de BFO stelden tijdens hun verblijf in Den Haag in onderling overleg de tekst van de grondwet vast en deelden die op 31 oktober aan 
Nederland en de UNCI mee; deze tekst werd als bijlage bij de RTC-akkoorden gevoegd.

Terwijl de Nederlandse delegatie niet betrokken was bij het overleg over de grondwet van de RVI, onderhandelde zij wel met de Indonesische delegaties over de formulering van de soevereiniteitsoverdracht en over het statuut van de Nederlands-Indonesische Unie. Volgens de overeenkomst van Linggadjati zouden Nederland en Indonesië (de deelgenoten) die Unie vormen ter behartiging van hun gemeenschappelijke belangen, waaronder samenwerking inzake buitenlandse betrekkingen en defensie; daartoe zou de Unie over eigen organen beschikken. De Nederlandse delegatie stelde als belangrijkste organen voor: een Unieraad, een Interparlementaire commissie en een Uniegerechtshof. De Indonesische delegaties verzetten zich hier krachtig tegen omdat dit toch te veel op een superstaat zou lijken. Het eindresultaat was een constructie die de vrijheid van de deelgenoten weinig beperkte. Als hoofdorgaan zou een tweemaal per jaar bijeenkomende ministersconferentie optreden. Hierin zouden telkens enkele ministers van de deelgenoten bijeenkomen; deze ministersconferenties zouden alleen met eenparigheid van stemmen besluiten mogen nemen; als zo'n besluit het uitvaardigen van een gemeenschappelijke regeling betrof zou daarvoor goedkeuring van de beide parlementen nodig zijn. Er kwam geen interparlementaire commissie; wel zouden de deelgenoten voor een goed contact en een geregelde samenwerking tussen hun parlementen zorgen. Verder zou de Unie over een permanent secretariaat en over een hof van arbitrage beschikken. Zoals al in Linggadjati overeengekomen was zou de Nederlandse koningin aan het hoofd van de Unie staan en zouden de deelgenoten zich over en weer niet door ambassadeurs maar door hoge commissarissen laten vertegenwoordigen. Ook zouden de deelgenoten ernaar streven hun buitenlands beleid zoveel mogelijk te coördineren.

Tot de op de RTC behandelde juridische kwesties behoorden de toescheiding van staatsburgers en de rechtspositie van de burgerlijke overheidsdienaren. Men kwam onder meer overeen dat in Indonesië geboren personen die volgens de Nederlandse wetgeving Nederlanders waren (voor het overgrote deel waren dit 'Indische Nederlanders', dus personen van gemengde Europees-Aziatische afkomst) nog gedurende twee jaar voor de Indonesische nationaliteit zouden kunnen kiezen

Wat de militaire onderwerpen betreft stelden de op de RTC getroffen overeenkomsten voorop, dat de verantwoordelijkheid voor de in- en uitwendige veiligheid van Indonesië, met inbegrip van de beveiliging ter zee en in de lucht, uitsluitend bij de regering van de RVI zou berusten. De uit Nederland uitgezonden land- en luchtstrijdkrachten zouden zo mogelijk binnen zes maanden gerepatrieerd worden; in afwachting van hun vertrek zouden ze in rayons worden verzameld. Ook de KNIL-militairen zouden voorlopig in die rayons bijeengebracht worden; later zouden ze deels in dienst kunnen 
treden bij de RVI, deels in Nederlandse dienst kunnen overgaan en deels moeten afvloeien. Het KNIL zelf zou midden 1950 ophouden te bestaan. De Nederlandse marine zou binnen een jaar uit Indonesië teruggetrokken worden, maar zou gedurende die tijd op verzoek van de RVI nog een aantal taken blijven verrichten. Ook zou Nederland aan de RVI een aantal marineschepen overdragen en zou het een marineofficier beschikbaar stellen als beheerder van de marinebasis Soerabaja. Verder zou na de soevereiniteitsoverdracht een Nederlandse militaire missie in Indonesië behulpzaam zijn bij de opbouw en opleiding van de strijdkrachten van de RVI.

Terwijl de Nederlandse delegatie veel concessies deed bij de staatkundige en militaire kwesties, kwamen de Indonesische delegaties bij de economische en financiële kwesties in aanzienlijke mate aan de Nederlandse wensen tegemoet. De op de RTC opgestelde overeenkomsten over de handelspolitieke en financiële betrekkingen en over de erkenning van rechten en vergunningen schiepen dan ook gunstige voorwaarden voor de voortzetting van de Nederlandse economische activiteiten in Indonesië. Hatta had trouwens al in zijn rede op de openingszitting van de RTC verwezen naar het in november 1945 door de Republiek gepubliceerde Politiek Manifest (zie p. 423) waarin zij verklaard had de rechten van de ondernemingen te zullen eerbiedigen. Wel rees er grote onenigheid over de overneming door de RVI van de schulden van het Nederlands-Indische gouvernement, die in totaal op 6,3 miljard gulden geschat werden. De Republikeinse delegatie wilde hier niet aan meewerken voorzover dit uitgaven betrof (geschat op 2 miljard gulden) ter financiering van de gewapende strijd tegen de Republiek. Dank zij bemiddeling van Cochran aanvaardde de Nederlandse delegatie uiteindelijk dat de RVI de schulden zou overnemen onder aftrek van het bedrag van 2 miljard.

Niettemin leek de RTC eind oktober alsnog schipbreuk te zullen lijden wegens twee kwesties die geen zakelijke belangen betroffen maar aan Nederlandse kant hevige emoties losmaakten: het externe zelfbeschikkingsrecht voor minderheden en de toekomst van Nieuw-Guinea (zie de volgende paragrafen). Op de valreep bereikten de delegaties over beide kwesties een compromis, met veel hulp van de UNCI. Daarna kon op 2 november eindelijk de formele slotzitting van de RTC plaatsvinden. De drie delegaties en de UNCI ondertekenden daarin een 'mantelresolutie' waaraan alle op de conferentie bereikte akkoorden als bijlagen gehecht waren en waarin bepaald werd dat de soevereiniteitsoverdracht uiterlijk op 30 december zou plaatsvinden.

\section{Het externe zelfbeschikkingsrecht voor Indonesische minderheden}

De kwestie van het externe zelfbeschikkingsrecht betrof in hoofdzaak twee minderheden, de Ambonezen en de Menadonezen. Hun stamlanden waren de 
zuidelijke Molukken en de Minahasa, twee gebieden waar de Verenigde OostIndische Compagnie zich al in de zeventiende eeuw stevig gevestigd had (zie pp. 27 en 38). Ambon, het belangrijkste eiland van de zuidelijke Molukken, was in 1605 het eerste steunpunt van de VOC in de Indonesische archipel geworden nadat zij daar op aandrang van de inheemse hoofden de Portugezen had verdreven. Die hoofden hadden zich toen bij verdrag tot eeuwige trouw aan Nederland verbonden en een flink deel van de bevolking was tot het christendom overgegaan. Een halve eeuw later had de VOC een steunpunt gekregen in Menado op Celebes nadat ook daar haar hulp ingeroepen was, in dit geval niet tegen de Portugezen maar tegen de Spanjaarden. Menado was de hoofdplaats van de Minahasa, het meest noordoostelijke deel van Celebes, en alle bewoners van dat gebied werden Menadonezen genoemd. In de negentiende eeuw waren zij bijna volledig tot het christendom overgegaan en sindsdien was de Minahasa het meest Nederlands-georiënteerde deel van Indonesië geworden. Omdat Nederland toen elf provincies telde werd het onder Menadonezen populair de Minahasa als Nederlands 'twaalfde provincie' te betitelen.

Al sinds de begintijd van de VOC waren mannen uit de Zuid-Molukken als soldaten in Nederlandse dienst getreden; later werd ook de Minahasa een belangrijke recruteringsbasis voor het koloniale leger. Verder werd op Ambon en in de Minahasa op ruimere schaal westers onderwijs gegeven dan in de rest van Nederlands-Indië. Een en ander droeg ertoe bij dat velen uit deze gebieden naar andere delen van de kolonie trokken, vaak in dienst van het koloniale gezag, niet alleen als militairen maar ook als ambtenaren en onderwijzers. Bij het einde van de Tweede Wereldoorlog bevonden tienduizenden Ambonezen en Menadonezen zich buiten de Molukken en de Minahasa. Tijdens het daarop uitbrekende grote conflict schaarde een deel van hen zich achter Nederland, terwijl een ander deel de kant van de Republiek koos. Met steun uit de hoek van het KNIL en van de Nederlandse marine kwam vervolgens binnen beide minderheden een separatistische organisatie tot stand die voor het eigen stamland ging streven naar een aparte status buiten de VSI maar met een nauwe band met Nederland. Eén van degenen die zich hiervoor inspanden was admiraal Helfrich, de bevelhebber van de Nederlandse zeestrijdkrachten. Hij gaf daartoe opdrachten aan admiraal Pinke, de marinecommandant in Indonesië.

De beide separatistische organisaties hadden hun aanhang vooral onder KNIL-militairen. De Ambonese organisatie heette Persatoean Timoer Besar (PTB, Vereniging Grote Oost); zij was op Java opgericht en streefde naar de afscheiding van een gebied dat alle Molukse eilanden en het Nederlandse deel van het eiland Timor zou omvatten. De PTB maakte er aanspraak op namens de hele bevolking van dat gebied op te treden, maar dit was zwaar overdreven. Alleen op de Zuid-Molukken had zij enige invloed, al steunde de ZuidMolukken-Raad het separatistische streven destijds niet. De bevolking van de 
Noord-Molukken was sterk Republikeinsgezind en ook op Timor genoot de PTB geen enkele steun. De Menadonese organisatie heette Twapro (afgeleid van Twaalfde Provincie); zij wilde van de Minahasa niet alleen figuurlijk maar ook formeel een Nederlandse provincie maken, met het 'Wilhelmus' als volkslied en het rood-wit-blauw als vlag. In de Minahasa-Raad bezette zij vijf van de vijfentwintig zetels.

Zowel het Nederlands-Indische gouvernement als de Nederlandse regering bejegende deze beide organisaties vriendelijk, maar moedigde hun streven niet aan. Men beschouwde hun doelstellingen als weinig reëel. Bovendien zou verwezenlijking ervan de positie van de federalisten binnen de RVI verzwakken. Dat deze weinig representatieve organisaties niettemin het welslagen van de Rondetafelconferentie hebben kunnen bedreigen, lag niet aan hun eigen kracht maar aan die van de Nederlandse oppositie tegen de dekolonisatie van Indonesië.

Die oppositie, aangevoerd door het Nationaal Comité Handhaving Rijkseenheid (zie p. 510), had sinds de Nederlandse verkiezingen van 1948 weinig meer van zich laten horen. Weliswaar waren daarbij twee van haar aanvoerders, Gerbrandy en Welter, tot lid van de Tweede Kamer gekozen, maar het starre verzet tegen de dekolonisatie had geen breed draagvlak meer onder het publiek. Toen in de zomer van 1949 de Rondetafelconferentie voor de deur stond leed het dan ook geen twijfel meer, dat het streven van het Nationaal Comité om Indonesië binnen het Koninkrijk te houden mislukt was. Niettemin besloot het Comité de strijd nog niet op te geven. Een deputatie, bestaande uit Gerbrandy, Meijer Ranneft, Welter en Winkelman, bracht begin augustus een bezoek aan koningin Juliana om er bij haar op aan te dringen niet aan de soevereiniteitsoverdracht mee te werken; zij probeerden haar te bewegen het kabinet-Drees naar huis te sturen en een nieuwe regering te vormen. Vervolgens belegde het Comité in augustus en september grote protestbijeenkomsten tegen het Indonesië-beleid van de regering. Bijna al haar kopstukken, zoals Feuilletau de Bruyn, Gerbrandy, Gerretson, Helfrich, Meijer Ranneft en Welter, voerden daar het woord.

$\mathrm{Nu}$ het Comité de scheiding tussen het Koninkrijk en Indonesië op zichzelf niet meer kon tegenhouden, spande het zich in om toch nog het meest oostelijke deel van de archipel binnen het Rijk te houden. Als gevolg daarvan deed zich het paradoxale fenomeen voor, dat juist zij die steeds betoogd hadden dat de Indonesiërs niet rijp waren om zichzelf te besturen zich nu opwierpen als kampioenen van het zelfbeschikkingsrecht voor Indonesische minderheden.

Intussen waren vertegenwoordigers van verschillende minderheidsgroepen uit Indonesië in Nederland aangekomen om hun belangen tijdens de Rondetafelconferentie te bepleiten. Daartoe behoorden ook enkele vertegenwoordigers van de PTB en de Twapro. Op de RTC was men bereid hen door een subcommissie te laten horen, maar PTB en Twapro wezen dit af en eisten 
toelating tot de conferentie als volwaardige deelnemers. De twee organisaties richtten een rekest aan de RTC waarin ze verklaarden dat de volken van de Minahasa, de Molukken en Timor buiten de RVI wensten te blijven, omdat de bijzondere banden die hen sedert drieënhalve eeuw met Nederland verbonden in geen geval verbroken mochten worden. Het Comité Handhaving Rijkseenheid liet de vertegenwoordigers van de beide organisaties het woord voeren op zijn protestvergaderingen. De rechtse pers gaf veel publiciteit aan hun verklaringen en deed het voorkomen alsof ze door de RTC werden geboycot.

Deze stelselmatige agitatie maakte diepe indruk op een deel van het Nederlandse publiek. In die kring twijfelde men er niet aan dat deze woordvoerders namens de hele bevolking van de Minahasa, de Molukken en Timor spraken. Men voelde zich schuldig tegenover deze inheemse volken die, naar men dacht, het slachtoffer van hun trouw aan Nederland dreigden te worden. Daarom zag men het als een morele plicht hun stamgebieden in staat te stellen buiten de toekomstige Indonesische staat te blijven nu die gedomineerd zou worden door de Republiek. Men wist in deze kring gewoonlijk niet dat de Ambonese en Menadonese minderheden ook talrijke leden telden die juist de kant van de Republiek gekozen hadden en dat verscheidene van hen daarin zelfs leidende posities innamen.

Artikel 3 van de overeenkomst van Linggadjati had voor Indonesische gebiedsdelen de mogelijkheid geopend om voor een eigen status buiten de VSI te kiezen; het voorzag dus in een extern zelfbeschikkingsrecht. De aan de RTC voorafgaande overeenkomst van 22 juni had bepaald dat de grondwet van de VSI de verwezenlijking van het recht op zelfbeschikking van de volkeren van Indonesië zou moeten garanderen, maar had niet aangegeven of dit ook een extern zelfbeschikkingsrecht zou moeten omvatten. Toen eind oktober eindelijk de tekst bekend werd van de door de Republiek en de BFO opgestelde grondwet bleek die alleen in een intern zelfbeschikkingsrecht te voorzien. Men had trouwens moeilijk anders kunnen verwachten. Niettemin bracht het ontbreken van een voorziening voor een extern zelfbeschikkingsrecht de Nederlandse parlementaire goedkeuring van de RTC-akkoorden in gevaar. Op de laatste conferentiedag aanvaardden de delegaties daarom een door de UNCI voorgestelde compromisformule, geldend voor de periode voordat de voorlopige grondwet plaats zou maken voor een definitieve. In theorie voorzag die formule in de mogelijkheid dat een Indonesisch gebied de definitieve grondwet zou afwijzen en dan zou mogen onderhandelen over een speciale verhouding tot de RVI en Nederland. In de praktijk zou dit niet echt tot afscheiding kunnen leiden, omdat de term 'onderhandelen' meebracht dat daartoe instemming van de RVI zelf nodig zou zijn.

Onmiddellijk na de sluiting van de RTC richtten de Twapro en de PTB een bezwaarschrift tot premier Drees waarin verklaard werd dat de volken van de 
Minahasa, de Molukken en Timor het overeengekomene volledig verwierpen en dat ze zich met alle beschikbare middelen zouden blijven verzetten tegen de schending van hun recht op zelfbeschikking. Eind november begon het Comité Handhaving Rijkseenheid onder de kop 'Redt de volken van Ambon, Timor en de Minahassa' een handtekeningenactie voor een verzoek aan het parlement om aan de eisen van deze drie volken te voldoen. Op 17 december, twee dagen voordat de Eerste Kamer de openbare behandeling van de RTCakkoorden begon, werd het verzoek met bijna 240.000 handtekeningen bij het parlement afgeleverd. Dit was de laatste grote actie van het Nationaal Comité; in februari 1950 hief het zich op.

\section{De kwestie Nieuw-Guinea}

Artikel 3 van de overeenkomst van Linggadjati had in een extern zelfbeschikkingsrecht voorzien in die zin dat, als de bevolking van een Indonesisch gebiedsdeel langs democratische weg te kennen zou geven niet tot de VSI te willen toetreden, men voor dat gebiedsdeel een bijzondere verhouding tot de VSI en tot Nederland in het leven zou kunnen roepen. Daarnaast voorzag artikel 4 van die overeenkomst in een intern zelfbeschikkingsrecht binnen de VSI. Maar toen het ontwerp van de overeenkomst in december 1946 in het Nederlandse parlement besproken werd, verklaarde de regering te wensen dat Nieuw-Guinea 'in de geest van de artikelen 3 en 4' een eigen status ten opzichte van Nederland en de VSI zou moeten kunnen krijgen ook zonder uitspraak daarover van de bevolking van het gebied (zie p. 508). De regering vond dit nodig, zo verklaarde minister Jonkman toen, om daar de mogelijkheid open te houden van volksplantingen van Indische Nederlanders die onder een eigen bestel zouden willen leven.

Ondanks de door de regering gebruikte woorden 'in de geest van de artikelen 3 en 4 ' hield deze verklaring geen interpretatie van het akkoord in, maar een afwijking ervan; anders gezegd: het was geen aankleding maar uitkleding van Linggadjati. Het ging ook helemaal niet over zelfbeschikking. Integendeel, de verklaring ging er juist van uit dat Nederland bevoegd bleef over de westelijke helft van Nieuw-Guinea te beschikken zonder de inheemse bevolking daarbij te raadplegen.

De aanleiding voor de verklaring van de regering was een optreden van Indische Nederlanders geweest tijdens een in oktober 1946 door Van Mook in Pangkalpinang belegde conferentie met vertegenwoordigers van minderheidsgroepen (zie p. 479). Zij hadden ervoor gepleit voor hun bevolkingsgroep op ruime schaal vestiging in Nieuw-Guinea mogelijk te maken en met het oog daarop aan dat gebied een van Indonesië afgescheiden eigen status binnen het Koninkrijk te geven. Deze pleidooien sloten aan bij een al voor de oorlog 
ontstane beweging voor transmigratie van Indo-Europeanen naar NieuwGuinea.

In december 1946 had het nieuwe standpunt van de regering meteen consequenties voor de toen door Van Mook in Denpasar belegde conferentie tot oprichting van de deelstaat Oost-Indonesië (zie pp. 512-4). Deze conferentie vormde een vervolg op de in juli 1946 in Malino gehouden conferentie over de federale opbouw van het toekomstige Indonesië (zie pp. 466-7). Maar terwijl aan die conferentie nog een vertegenwoordiging van Nieuw-Guinea deelgenomen had, nodigde het gouvernement op instructie van Den Haag voor Denpasar geen vertegenwoordigers van dat gebied uit en legde het aan deze conferentie een ontwerp-constitutie voor die Nieuw-Guinea van het grondgebied van Oost-Indonesië uitzonderde. Tegen die uitzondering werd in Denpasar ernstig bezwaar gemaakt, onder meer door de Balinese afgevaardigde Anak Agoeng. Het gouvernement bleef echter onverzettelijk: als de conferentie dit niet wilde aanvaarden zou de oprichting van de deelstaat niet doorgaan. Uiteindelijk zwichtte men voor deze druk, nadat Van Mook onder meer gezegd had dat de uitzondering slechts een voorlopig karakter had en dat het bepaald niet de bedoeling van de regering was om Nieuw-Guinea buiten Indonesië te sluiten.

De Nederlandse regering wenste echter wel degelijk de mogelijkheid open te houden om Nederlands-Nieuw-Guinea van Indonesië af te scheiden. Dit kon verbazing wekken omdat Nederland dat gebied altijd als een deel van Nederlands-Indië behandeld had. In de bestuurlijke indeling van de kolonie had Nieuw-Guinea tot voor kort zelfs geen apart gebied gevormd, maar had het deel uitgemaakt van het bestuursdistrict ('residentie') Molukken, waarvan het hoofd op Ambon zetelde. Voor de Tweede Wereldoorlog had Nederland zich weinig met het gebied beziggehouden, al had het er wel gebruik van gemaakt om politieke dissidenten in Boven-Digoel te interneren (zie pp. 2023). Pas tijdens die oorlog was het gebied meer in de belangstelling gekomen toen het zuiden met de kustplaats Merauke het enige deel van Indonesië was dat niet door de Japanners bezet werd en toen Amerikaanse strijdkrachten het noorden veroverden en daar militaire bases inrichtten. In 1946 was NieuwGuinea een afzonderlijke residentie geworden met Hollandia als hoofdplaats, maar het was blijven behoren tot het bestuursgewest 'Grote Oost' dat nu in de deelstaat Oost-Indonesië getransformeerd werd; bovendien was het grootste deel ervan formeel nog steeds onderhorig aan een Molukse vorst, de sultan van Tidore.

In 1947 en 1948 stelde Nederland het onderwerp Nieuw-Guinea niet aan de orde bij het overleg met de Republiek over de uitvoering van het akkoord van Linggadjati en over de uitvoering van het Renville-akkoord. Intussen bleven particuliere organisaties actie voeren voor het ontwikkelen van Nieuw-Guinea tot vestigingsgebied voor Nederlanders, zowel uit Indonesië als uit Nederland 
zelf. Van de belangrijkste van die organisaties werd de Nederlandse afdeling voorgezeten door Feuilletau de Bruyn. Ook twee andere leden van het Nationaal Comité Handhaving Rijkseenheid, Meijer Ranneft en Welter, waren actieve voorvechters van bestendiging van de Nederlandse band met NieuwGuinea. De verschillende actiegroepen stichtten een samenwerkingsverband dat in september 1948 een petitie tot regering en parlement richtte voor de verlening van een eigen status aan Nieuw-Guinea op basis van de Nederlandse soevereiniteit. Een maand later hield Welter zelf in het parlement een vurig betoog over de politieke en economische betekenis van Nieuw-Guinea voor de toekomst van het Nederlandse volk. Hij kreeg onder meer bijval van Tilanus, de leider van de CHU.

De regering wilde zich lange tijd niet ten aanzien van de toekomstige status van Nieuw-Guinea vastleggen. Het initiatief om dit gebied niet over te dragen ging binnen de regering uit van premier Drees en minister Van Maarseveen. In maart 1949 stelde Drees in de ministerraad dat Nieuw-Guinea geen onderdeel van Indonesië was. In aansluiting daarop noemde Van Maarseveen het wenselijk dit gebied buiten de soevereiniteitsoverdracht te houden. Begin juni gaf hij in de raad een nadere argumentatie hiervoor. Daarbij noemde hij vijf redenen - dat Indonesië geen moreel recht op het gebied had, dat Nederland beter in staat was het gebied te ontwikkelen, dat het voor Nederland van betekenis was in Azië een pied-à-terre te behouden voor Nederlandsgezinde personen uit Indonesië, dat de Nederlandse scheepvaart belang bij de havens van Nieuw-Guinea had en dat het gebied zou kunnen bijdragen tot vermindering van de overbevolking in Nederland.

Het behartigen van de belangen van de inheemse bevolking van NieuwGuinea, de Papoea's, werd door Van Maarseveen niet als reden genoemd, evenmin als Jonkman gedaan had in zijn verklaring van december 1946. Ook sprak hij niet over de noodzaak van het verkrijgen van voldoende parlementaire steun voor de soevereiniteitsoverdracht als argument om Nieuw-Guinea daarvan uit te zonderen. Toch mag men aannemen dat dit laatste het eigenlijke motief was.

Dit parlementair-rekenkundige motief hield verband met twee zeer verschillende zaken: de in 1948 ingevoerde wijziging van de Nederlandse grondwet (zie pp. 581-2) en de in hetzelfde jaar op Java uitgebroken Madioenopstand (zie pp. 596-7). De gewijzigde grondwet opende de mogelijkheid Indonesië van het Koninkrijk af te scheiden, maar bepaalde dat daartoe in het parlement een meerderheid van twee derde nodig zou zijn. De PvdA en de KVP hadden daar samen wel een gewone maar geen tweederde meerderheid. Daarentegen beschikten ze samen met de communistische partij CPN wel over meer dan tweederde van de zetels, zowel in de Tweede als in de Eerste Kamer. De communisten hadden zich altijd voor Indonesische onafhankelijkheid uitgesproken en in december 1946 was de CPN de enige partij geweest die samen met PvdA 
en KVP voor de ondertekening van het akkoord van Linggadjati gestemd had. Maar sinds de onderdrukking van de communistische Madioenopstand was de CPN de Republiek vijandig gezind geworden; zij stelde Soekarno en Hatta voor als handlangers van het Amerikaanse imperialisme. Men moest er nu dus rekening mee houden dat de CPN tegen de soevereiniteitsoverdracht zou stemmen. Dit maakte het veel meer dan vroeger nodig voor die overdracht steun te zoeken bij de VVD en de CHU. Drees en Van Maarseveen voorzagen dat de regering voor het bereiken van een akkoord met de Republiek tal van concessies zou moeten doen waartegen binnen die partijen bezwaren zouden bestaan. Vasthouden aan Nieuw-Guinea leek nu het beste middel om die bezwaren te overwinnen.

Op instructie van Den Haag verbrak het Nederlands-Indische gouvernement de formele band tussen Nieuw-Guinea en het sultanaat Tidore. De delegatie die in Batavia onderhandelde over de uitvoering van het akkoord tussen Roem en Van Roijen kreeg opdracht Nieuw-Guinea op de agenda van de Rondetafelconferentie te plaatsen. De delegaties van de Republiek en de BFO maakten hier bezwaar tegen. Uiteindelijk werd dit twistpunt aldus opgelost dat men op 22 juni bij de vaststelling van het programma voor de RTC wel Nieuw-Guinea als agendapunt opnam, maar dat de Indonesische delegaties daarbij verklaarden hier alleen mee in te stemmen op voorwaarde dat men zich bewust was van hun standpunt dat dit gebied deel van de VSI zou moeten vormen.

Toen Van Maarseveen in de tweede helft van juni zelf in Batavia was liet hij zich door ambtenaren van het Nederlands-Indische gouvernement over de ontwikkelingsmogelijkheden van Nieuw-Guinea voorlichten. De door hem geraadpleegde departementshoofden uitten zich daar uitermate sceptisch over. Vasthouden van dit gebied zou volgens hen aan Nederland enorme sommen gaan kosten en zou de politieke verhouding met het Indonesische volk ernstig schaden. Van Maarseveen liet zich echter niet van zijn koers afbrengen. Kort daarna werd Van Mook door het departement van buitenlandse zaken over de kwestie Nieuw-Guinea geraadpleegd. Hij reageerde met een uitvoerig betoog waarin hij op grond van zowel praktische als principiële argumenten ontraadde dit gebied bij Nederland te houden. Onder meer merkte hij op dat Nederland riskeerde een belangrijk deel van de laatste resten goodwill in Indonesië kwijt te raken voor een object met alleen sentimentswaarde. Zijn advies werd niet onder de leden van het kabinet verspreid.

Het feit dat de Nederlandse regering Nieuw-Guinea op de agenda van de RTC geplaatst wilde zien wekte ongerustheid aan Indonesische kant. Soekarno sprak Van Roijen hierover aan toen deze hem midden juli in Jogja bezocht; hij waarschuwde dat de kwestie een gevaarlijk struikelblok op de conferentie zou kunnen worden. Toen Van Roijen opmerkte dat Hatta weinig persoonlijke belangstelling voor Nieuw-Guinea aan de dag legde zei Soekarno 
over zichzelf: 'Ik ben een Nieuw-Guinea-fanaticus'.

In de nota die Van Maarseveen begin augustus aan het parlement stuurde over de resultaten van de voorbereidende conferentie stond over NieuwGuinea, dat de regering vasthield aan het in december 1946 ingenomen standpunt dat dit gebied een eigen status ten opzichte van Nederland en de VSI zou moeten kunnen krijgen. In deze zelfde tijd kwam een grote actie op gang van de organisaties die van Nieuw-Guinea een vestigingsgebied voor Nederlanders wilden maken; zij zorgden voor een stortvloed van brieven, petities en telegrammen aan regering en parlement. Toen op 16 en 17 augustus het parlementaire debat over de komende RTC plaatsvond, verklaarden de sprekers uit de rechtse oppositie zich, zoals te verwachten, voor handhaving van de Nederlandse soevereiniteit over Nieuw-Guinea. Een nieuwe ontwikkeling was dat van de regeringspartijen nu niet alleen de CHU maar ook de VVD zich hierbij aansloot. Als spreker voor de PvdA liet Schermerhorn een tegengeluid horen: hij betoogde dat het belang van Nederland bij de samenwerking met de RVI lag en dat men er beter aan deed dit niet in de waagschaal te stellen terwille van het behoud van Nieuw-Guinea. Ook de leider van de KVP, Romme, voerde het woord in dit debat, maar over Nieuw-Guinea sprak hij niet.

Volgens de voorstellen die Nederland aan de RTC voorlegde zou NieuwGuinea buiten de soevereiniteitsoverdracht moeten blijven. Voor de Republiek en de BFO was dit volstrekt onaanvaardbaar. Afgezien van de persoonlijke meningen van de afgevaardigden hadden ook zij met een probleem van parlementaire rekenkunde te maken. Als de delegaties van de Republiek en de BFO de Indonesische aanspraken op Nieuw-Guinea opgaven, zoals de Nederlandse delegatie verlangde, werd niet alleen de kans klein dat het KNIP de resultaten van de RTC zou goedkeuren, maar werd het bovendien volstrekt zeker dat het parlement van Oost-Indonesië die resultaten zou verwerpen. Bij hun bestrijding van de Nederlandse eis beriepen de Indonesische delegaties zich onder meer op Van Mook's uitspraak uit december 1946 in Denpasar, op de tekst van het akkoord van Linggadjati en van het Renville-akkoord en op het recente gebruik van de term 'volledige soevereiniteit' in de verklaring van Van Roijen van 7 mei en in de tripartiete overeenkomst van 22 juni. Aan Indonesische kant nam Anak Agoeng de leiding bij de onderhandelingen over deze kwestie. Hij deed onder meer een tussenvoorstel: Nieuw-Guinea zou deel van de RVI uitmaken, maar de beide Uniepartners zouden een overeenkomst kunnen sluiten over sociale, culturele en economische aspecten ervan, met inbegrip van de mogelijkheid van volksplantingen. De Nederlandse delegatie wees dit af; zij was wel bereid tot bepaalde afspraken met de RVI over de toekomst van Nieuw-Guinea, maar de soevereiniteit zou bij Nederland moeten blijven.

Het gouvernement in Batavia was eenstemmig van oordeel dat NieuwGuinea aan Indonesië overgedragen moest worden en liet dit ook aan Van Maarseveen weten. Ook Van Roijen vond dat Nederland niet tot iedere prijs 
aan Nieuw-Guinea moest vasthouden. In de Nederlandse ministerraad vond echter nooit een discussie plaats over de vraag of men de RTC op de kwestie Nieuw-Guinea moest laten stranden. Voordat men aan die vraag toekwam stelde de UNCI als noodoplossing voor, de kwestie een jaar uit te stellen. Op deze basis bereikten de drie delegaties eind oktober een compromis. Men sprak af in het Charter van Soevereiniteitsoverdracht op te nemen dat de status quo van de residentie Nieuw-Guinea gehandhaafd zou worden, maar dat de staatkundige status ervan binnen een jaar bepaald zou worden door onderhandelingen tussen de RVI en Nederland. In een hierbij horende briefwisseling legden de drie delegaties vast dat handhaving van de status quo in deze bepaling voortzetting van het Nederlandse gezag betekende.

Dit was het begin van het geschil over Nieuw-Guinea, dat noodlottig zou blijken voor het voortbestaan van een nauwe band tussen Nederland en Indonesië. Het vasthouden van Nieuw-Guinea vond zijn oorsprong in een wens die destijds in hoofdzaak bij de rechtse partijen leefde. Hun argumentatie voor het behoud van Nieuw-Guinea verschoof overigens van het openstellen van het gebied voor de vestiging van Nederlanders naar het beschermen en bijstaan van de Papoeabevolking. Het eerste argument was in feite strijdig met het tweede. Aan de andere kant was dit nieuwe argument weinig geloofwaardig omdat Nederland die bevolking tot voor kort volstrekt verwaarloosd had. De werkelijke motieven voor het vasthouden van Nieuw-Guinea lagen elders en waren van psychologische aard. Terwijl het in 1945 voor de meeste Nederlanders nog vanzelf sprak dat Indonesië bij Nederland hoorde, waren zij in 1949 wel gaan inzien dat de dekolonisatie ervan onvermijdelijk was, maar deze overgang was erg snel gegaan en betekende voor velen een traumatische ervaring. Dit gold vooral binnen het protestantse deel van de bevolking, waar men algemeen gewend was de band met 'Indië' als een bestanddeel van de nationale identiteit te zien. Het vasthouden van Nieuw-Guinea zou dan enigszins als pleister op de wonde kunnen dienen. Men stelde zich voor dat dit vrijwel ongerepte gebied nog een arbeidsveld voor Nederlandse ondernemingsgeest en Nederlandse roepingsdrang kon worden en dat Nederland door het behoud van een presentie in Azië toch nog een zekere rol op het wereldtoneel zou kunnen spelen.

Aan Indonesische kant lagen de motieven om Nieuw-Guinea in de RVI op te nemen eveneens vooral in het psychologische vlak. Men had weinig zakelijk belang bij het gebied en de meeste Indonesiërs voelden zich met de Papoea's niet verwant. Maar Nieuw-Guinea maakte deel van NederlandsIndië uit zoals de Indonesiërs het in hun schooljaren op de kaart hadden leren kennen. De nationale beweging had haar doel omschreven als onafhankelijkheid 'van Sabang tot Merauke'. Bovendien had die beweging een bijzondere band met het gebied omdat Nederland daar voor de oorlog honderden nationalisten geïnterneerd had (onder wie Hatta en Sjahrir). De door Nederland 
gewenste uitzondering voor Nieuw-Guinea deed dan ook ernstig afbreuk aan de erkenning van de Indonesische onafhankelijkheid. Voor Anak Agoeng was het bovendien een persoonlijk affront. Hoewel hij zich steeds tegen de afscheiding van Nieuw-Guinea gekeerd had, was hij van 1946 af één van de belangrijkste steunpilaren van het Nederlandse federaliseringsbeleid geweest. Dat Nederland nu Nieuw-Guinea toch van Indonesië afscheidde ondermijnde zijn positie in de deelstaat Oost-Indonesië.

\section{De tekst van het Charter van Soevereiniteitsoverdracht}

De op de Rondetafelconferentie overeengekomen tekst van het Charter van Soevereiniteitsoverdracht luidde als volgt:

Artikel 1

1. Het Koninkrijk der Nederlanden draagt de volledige souvereiniteit over Indonesië onvoorwaardelijk en onherroepelijk over aan de Republiek der Verenigde Staten van Indonesië en erkent deze mitsdien als een onafhankelijke en souvereine Staat.

2. De Republiek der Verenigde Staten van Indonesië aanvaardt deze souvereiniteit op de voet van de bepalingen van haar Constitutie, welke in ontwerp ter kennis is gebracht van het Koninkrijk der Nederlanden.

3. De overdracht van de souvereiniteit zal plaats hebben uiterlijk 30 December 1949.

Artikel 2

Ten aanzien van de residentie Nieuw-Guinea is overeengekomen:

a. gezien het feit, dat het nog niet mogelijk is gebleken de standpunten van partijen nopens Nieuw-Guinea overeen te brengen, waardoor deze in geschil blijven,

b. gezien de wenselijkheid om de Rondetafelconferentie met goed resultaat te beëindigen op 2 November 1949,

c. gezien de belangrijke factoren, die in ogenschouw moeten worden genomen bij de oplossing van het vraagstuk Nieuw-Guinea,

d. gezien het beperkte onderzoek, dat kon worden ingesteld en voltooid ten aanzien van de problemen, die samenhangen met het vraagstuk Nieuw-Guinea,

e. gezien de moeilijke taak, waarvoor de deelgenoten in de Unie zich al dadelijk zullen zien gesteld, en,

f. gezien de beslotenheid van partijen tot handhaving van het beginsel om door vredelievende en redelijke middelen alle geschillen op te lossen, die later mochten blijken te bestaan of te rijzen,

dat de status quo van de residentie Nieuw-Guinea zal worden gehandhaafd met de bepaling, dat binnen een jaar na de datum van overdracht van de souvereiniteit aan de Republiek der Verenigde Staten van Indonesië het vraagstuk van de staatkundige status van Nieuw-Guinea zal worden bepaald door onderhandelingen tussen de Republiek der Verenigde Staten van Indonesië en het Koninkrijk der Nederlanden. 
Hierbij behoorde een briefwisseling tussen de voorzitter van de Nederlandse delegatie enerzijds en de voorzitters van de delegaties van de Republiek en de $\mathrm{BFO}$ anderzijds waarin werd gesteld:

De zinsnede in artikel 2 van het ontwerp-Charter van Souvereiniteitsoverdracht, luidende: 'de status quo van de residentie Nieuw-Guinea zal worden gehandhaafd' betekent: 'met voortzetting van het gezag van de Regering van het Koninkrijk der Nederlanden over de residentie Nieuw-Guinea'.

Artikel 1 van het Charter bevatte noch expliciet noch impliciet een verwijzing naar artikel 2. Dit maakt het twijfelachtig of dat tweede artikel de strekking van het eerste wel kon beperken. Bovendien hield artikel 1 ook in dat de RVI de soevereiniteit op basis van haar Constitutie aanvaardde, terwijl die Constitutie uitdrukkelijk stelde dat de RVI het gehele grondgebied van Indonesië omvatte. Verder kwam in artikel 2 het woord 'soevereiniteit' in het geheel niet voor, evenmin als in de bijbehorende briefwisseling. Men kan hieruit concluderen dat de overdracht van 'de volledige souvereiniteit over Indonesië' volgens het Charter ook op Nieuw-Guinea betrekking had en dat het in artikel 2 neergelegde voorbehoud over 'de staatkundige status van Nieuw-Guinea' wel allerlei aspecten van die status kon betreffen, maar niet de soevereiniteit.

De in de briefwisseling neergelegde uitleg, dat handhaving van de status quo moest worden verstaan als voortzetting van het Nederlandse gezag, bracht hier geen verandering in. Uitoefening van gezag en bezit van soevereiniteit hoeven niet samen te vallen. Dat tijdens de Tweede Wereldoorlog het grondgebied van Nederland onder Duits gezag en dat van Indonesië onder Japans gezag stond werd niet als aantasting van de Nederlandse soevereiniteit gezien. Hetzelfde gold voor de onderschikking van het Nederlandse gezag in Indonesië aan het Britse gezag in 1945-1946. Verder had de Nederlandse regering in het akkoord van Linggadjati zelf de regering van de Republiek erkend als de facto het gezag uitoefenend over Java, Madoera en Sumatra, zonder dat zij daarmee afstand deed van de Nederlandse soevereiniteit over die gebieden.

De betekenis van de op de RTC overeengekomen formules kan ook worden toegelicht door vergelijking met de oorspronkelijk door de Nederlandse delegatie voorgestelde teksten. In die voorstellen had de aanhef van artikel 1 geluid: 'Het Koninkrijk der Nederlanden draagt met inachtneming van het bepaalde in dit Charter de souvereiniteit over Indonesië bij deze over aan de Verenigde Staten van Indonesië'. Door de woorden 'met inachtneming van het bepaalde in dit Charter' bevatte die tekst dus wél een uitdrukkelijke verwijzing naar de overige bepalingen. Vervolgens stond in ontwerp-artikel 2 dat Nieuw-Guinea niet was begrepen 'onder de overdracht van souvereiniteit over Indonesië'. Het is duidelijk waarom deze formuleringen in het overleg met de Indonesische delegaties niet in stand gebleven zijn. 
Ondanks de uiteindelijk in overeenstemming met de Indonesische zienswijze tot stand gekomen formulering van de soevereiniteitsoverdracht heeft Nederland zich op het standpunt gesteld dat de soevereiniteit over NieuwGuinea daarbij niet aan de RVI overgedragen werd.

\section{De soevereiniteitsoverdrachten}

Na de sluiting van de RTC op 2 november 1949 was nog anderhalve maand beschikbaar voor de goedkeuring van de bereikte akkoorden door de parlementaire organen van Nederland, de Republiek en de bij de BFO aangesloten deelstaten en autonome gebieden. In de meeste in de BFO samenwerkende gebieden verliep de goedkeuringsprocedure zonder problemen. Moeilijker ging het in het parlement van Oost-Indonesië, dat zowel voor als tijdens de RTC verklaard had dat Nieuw-Guinea bij Indonesië moest blijven. Premier Anak Agoeng moest zich dan ook in Makassar verdedigen tegen het verwijt dat hij van zijn mandaat afgeweken was. Uiteindelijk wist hij zijn parlement ervan te overtuigen dat hij onmogelijk de verantwoordelijkheid op zich had kunnen nemen de hele RTC op dit ene punt te laten mislukken.

In de Republiek werden de RTC-akkoorden ter goedkeuring voorgelegd aan de voorlopige volksvertegenwoordiging, het KNIP. Dat die goedkeuring zou worden verkregen stond eind november al vast toen de akkoorden ruime steun kregen in het Werkcomité van het KNIP. Intussen was bijeenroeping van het plenaire KNIP niet eenvoudig, want het had niet meer vergaderd sinds het in maart 1947 het ontwerp-akkoord van Linggadjati besprak (zie p. 524). Sindsdien had Nederland in twee grote militaire acties bijna het hele grondgebied van de Republiek bezet en had de Republiek intern het hoofd moeten bieden aan de Madioenopstand. Van de 535 leden van het KNIP waren velen verspreid geraakt en hadden sommigen het leven verloren, hetzij in de strijd met Nederland hetzij in onderlinge conflicten. De nieuwe zitting begon in Jogja op 6 december en werd door 319 leden bijgewoond. Het debat duurde een week; de kritiek richtte zich vooral op de voor Nederland bijzonder gunstige economische regelingen en op de uitzondering van Nieuw-Guinea. Hatta beet fel van zich af; uiteindelijk keurde het KNIP op 14 december de RTC-akkoorden goed met 226 voorstemmen naast 62 tegenstemmen en 31 onthoudingen. De twee grootste partijen, de Masjoemi en de PNI, stemden voor; de tegenstemmen kwamen vooral van de linkse oppositie wier standpunten strookten met die van de nieuwe PP (Pembela Proklamasi); de onthoudingen kwamen onder meer van de socialistische partij van Sjahrir.

In Nederland begon de openbare behandeling van het voorstel tot goedkeuring van de overeenkomsten eveneens op 6 december in de Tweede Kamer. Het hele kabinet woonde het debat bij; het zou aftreden als de vereiste 
tweederde meerderheid niet bereikt werd. Alle honderd leden van de Kamer waren aanwezig. Op 9 december werd het voorstel aangenomen met 71 tegen 29 stemmen. Naast de fracties van PvdA (27) en KVP (32) had de hele VVDfractie (8) voorgestemd, terwijl van de CHU-fractie 4 leden voor- en 5 tegengestemd hadden; de verdere tegenstemmen kwamen van ARP (13), SGP (2), Welter (1) en CPN (8). In de Eerste Kamer werd het voorstel op 21 december aangenomen met 34 stemmen voor en 15 tegen. De fracties van PvdA (14), KVP (17) en VVD (3) stemden voor; de hele CHU-fractie (5) stemde tegen, samen met ARP (6) en CPN (4); één ARP-lid was wegens ziekte afwezig. Het was een krappe overwinning: had één VVD-lid tegengestemd en was de ARPfractie voltallig geweest, dan zou de vereiste meerderheid niet gehaald zijn.

De behandeling in de Eerste Kamer was met spanning tegemoetgezien, omdat de uitslag tot het laatst onzeker was. De regering in Den Haag had daarom alles willen vermijden dat de indruk kon wekken dat men de Kamer voor voldongen feiten plaatste. Het gouvernement in Batavia had zulke feiten echter moeilijk geheel kunnen vermijden. Voor een enigszins ordelijke overgang van het oude naar het nieuwe regiem moesten nu eenmaal voorbereidingen worden getroffen die men niet tot eind december kon uitstellen. Dit betrof onder meer de terugtrekking en concentratie van de Nederlandse strijdkrachten. Vrijwel dagelijks droegen Nederlandse troepenonderdelen op Java en Sumatra de verantwoordelijkheid voor bepaalde gebieden aan Republikeinse strijdkrachten over. Dit gebeurde niet alleen in het gebied dat in het Nederlandse offensief van december 1948 bezet was, maar ook in delen van het al in juli 1947 bezette gebied. Om te verzekeren dat de TNI en de Republikeinse politie bij de soevereiniteitsoverdracht de zorg voor de openbare veiligheid geruisloos konden overnemen was het bovendien nodig tijdig ook contingenten ervan te legeren in de gebieden die al voor juli 1947 in Nederlandse handen waren, met inbegrip van steden als Soerabaja, Bandoeng en Batavia. De regering in Den Haag schrok echter toen in de Nederlandse pers bekend werd dat op 10 december in Batavia al de eerste TNI-eenheden aangekomen waren; zij haastte zich te verklaren dat het alleen om kwartiermakers ging. Overigens werd de orde in Batavia vanaf medio december gehandhaafd door gemengde patrouilles van gemeentepolitie en Republikeinse politie.

De noodzaak van samenwerking tussen de Nederlandse en de Republikeinse autoriteiten ter vermijding van een gezagsvacuum betrof niet alleen de zorg voor de openbare veiligheid maar ook de civiele regeringstaken. Al op 3 november nodigde het gouvernement daarom de Republiek en de BFO uit om vertrouwensmannen aan te wijzen die zich op de verschillende departementen op de hoogte zouden kunnen stellen van de bestaande organisatie en van de daar behandelde problemen. Ook sprak het de hoop uit spoedig met vertegenwoordigers van de RVI overleg te kunnen plegen over kwesties van algemeen beleid. Met het eerste punt stemde men van Indonesische kant al 
spoedig in; aan het tweede punt kwam men enige weken later tegemoet. Op 26 november richtten de Republiek en de BFO namelijk een bijzonder orgaan op voor het begeleiden van de gezagsovergang, de Panitia Persiapan Nasional (PPN, Nationale Voorbereidingscommissie). De naam herinnerde aan die van de commissie die in 1945 de onafhankelijkheid voorbereid had, de Panitia Persiapan Kemerdekaan Indonesia (zie pp. 341-3 en 359-60). De hoofdtaken van de PPN betroffen de totstandkoming van de noodzakelijke organen van de RVI en de voorbereiding van het overnemen van de overheidstaak door de RVI-regering van het Nederlands-Indische gouvernement.

De PPN bestond uit eenendertig leden, van wie vijftien door de Republiek en zestien door de BFO aangewezen waren. Voorzitter was Roem, vicevoorzitter Anak Agoeng. De PPN vormde subcommissies voor de behandeling van bepaalde onderwerpen; het geheel stond onder leiding van een stuurgroep van acht leden. Van Nederlandse kant richtte men voor de geregelde samenwerking met de PPN een eveneens uit acht personen bestaande contactgroep van hoog niveau op onder leiding van H.L. s'Jacob. Deze groep kon zowel namens het gouvernement als namens de Nederlandse regering optreden. Ook de stafchefs van de Nederlandse landstrijdkrachten en marine maakten er deel van uit.

In de laatste weken die aan de overdracht van de Nederlandse soevereiniteit voorafgingen leek Indonesië niet meer door het Nederlands-Indische gouvernement maar door de PPN geregeerd te worden. Zij droeg de verantwoordelijkheid voor de handhaving van orde en rust in heel Indonesië op aan de sultan van Jogja, Hamengkoe Boewono IX. Zij ontving de rapporten van de vertrouwensmannen die zich op de departementen in Batavia georienteerd hadden en nam die departementen daarna over. Ze vaardigde tal van voorschriften uit, bijvoorbeeld over de onderscheidingstekens van de verschillende soorten politie en over het gebruik van de nationale vlag en van andere vlaggen. Verder hield ze zich actief met voorlichting bezig. Elke dag op dezelfde tijd werden haar communiqués over alle radiozenders uitgezonden in het Indonesisch, het Nederlands en het Engels. Zij liet een voorlichtingsfilm maken die in de bioscopen vertoond werd. In Batavia schakelde zij studenten en scholieren in om ervoor te zorgen dat haar bekendmakingen ook in alle volkswijken verspreid werden.

Omdat het Nederlandse parlement de RTC-akkoorden nog niet goedgekeurd had bemantelde men diplomatiek dat de PPN in de praktijk gezag uitoefende. Een deel van haar voorschriften droeg de naam 'adviezen' en de sultan heette slechts 'coördinator', hoewel hij in feite de supervisie had over zowel de TNI als de Nederlandse strijdkrachten, de veiligheidsbataljons en de politie.

Intussen wijdde de PPN zich ook aan haar andere hoofdtaak, de voorbereiding van het formele staatsapparaat van de RVI. Op 14 december kwamen 
gemachtigden van de Republiek en de BFO-gebieden in Batavia bijeen in het historische pand aan Pegangsaän Oost 56 en ondertekenden daar de voorlopige RVI-constitutie. Op 16 december kwamen de gemachtigden in Jogja bijeen en kozen daar Soekarno en Hatta tot eerste president en vicepresident van de nieuwe staat. De volgende dag werden deze twee beëdigd; daarna legde Soekarno een krans op het graf van de eerste organisator van het Republikeinse leger, Oerip Soemohardjo, die in november 1948 gestorven was. Soekarno wees vier kabinetsformateurs aan om een nationaal kabinet te vormen, Hatta, Anak Agoeng, sultan Hamengkoe Boewono IX en sultan Hamid II. Dank zij de voorbereidingen van de PPN slaagden die in uiterst korte tijd in de vorming van een kabinet; op 20 december werd het door Soekarno geïnstalleerd. Dit eerste kabinet van de RVI bestond uit zestien ministers; Hatta werd premier en minister van buitenlandse zaken, Anak Agoeng minister van binnenlandse zaken en de sultan van Jogja minister van defensie; Roem en sultan Hamid werden minister zonder portefeuille. Overigens werd Roem kort daarna tot Hoge Commissaris van de RVI in Nederland benoemd. De PPN bereikte ook overeenstemming over de samenstelling van het voorlopige parlement van de RVI, waarvan een derde deel uit de Republiek en twee derde uit de overige deelstaten zou komen.

Verder pleegde de PPN overleg met Nederland over de organisatie van de plechtigheden waarbij de Nederlandse soevereiniteit en het Nederlandse bestuur over Indonesië aan de RVI zouden worden overgedragen. Ook trof ze voorbereidingen voor de overdracht in Jogja van de op de onafhankelijkheidsverklaring van 1945 gebaseerde soevereiniteit van de Republiek. Als datum kwam men 27 december overeen.

De in december ondernomen stappen met het oog op de toekomstige situatie betroffen ook het interinsulaire bedrijf van de Nederlandse luchtvaartmaatschappij KLM. Dit bedrijf, dat het luchtverkeer binnen de Indonesische archipel verzorgde, was voor de helft eigendom van de KLM en voor de helft van het gouvernement. Op 21 december sloot de KLM een overeenkomst met de regering van de RVI waarbij het bedrijf in een Indonesische luchtvaartmaatschappij werd omgezet, Garuda Indonesian Airways.

Anders dan veel Nederlanders in de afgelopen maanden gevreesd hadden was de sfeer aan de vooravond van de soevereiniteitsoverdracht vreedzaam en ontspannen. Nederlandse en Republikeinse militairen bleken gemoedelijk met elkaar te kunnen omgaan. Op 25 december werd in Batavia een vriendschappelijke voetbalwedstrijd gespeeld tussen een elftal van het Nederlandse garnizoen en een elftal van de Siliwangidivisie, in aanwezigheid van de sultan van Jogja en verscheidene hoge Nederlandse en Republikeinse officieren.

De overdrachten van de Nederlandse soevereiniteit en het Nederlandse bestuur over Indonesië en van de soevereiniteit van de Republiek vonden op 27 december 1949 plaats in drie plechtigheden die elkaar gedeeltelijk overlapten. 
Eén ceremonie begon 's ochtends om tien uur in het koninklijk paleis in Amsterdam, niet ver van het vroegere hoofdkwartier van de Verenigde Oost-Indische Compagnie. Koningin Juliana en de volledige Nederlandse regering namen hieraan deel, terwijl de RVI vertegenwoordigd werd door een delegatie onder leiding van Hatta waar verder onder meer sultan Hamid toe behoorde. Drees en Hatta ondertekenden een aantal documenten, waaronder het Charter van Soevereiniteitsoverdracht en het Uniestatuut. Daarna ondertekende koningin Juliana een aparte acte die inhield dat de soevereiniteitsoverdracht in overeenstemming met het Charter rechtskracht had verkregen, dat de Nederlands-Indonesische Unie tot stand gekomen was en dat alle bij de mantelresolutie van de RTC horende akkoorden in werking waren getreden. Nadat deze acte door alle Nederlandse ministers medeondertekend was, hield de koningin een korte toespraak.

Gelijktijdig met de plechtigheid in Amsterdam begon in Batavia/Djakarta, waar het toen vijf uur 's middags was, de ceremonie voor de bestuursoverdracht in het vroegere paleis van de gouverneur-generaal. De RVI werd hier vertegenwoordigd door een delegatie onder leiding van de sultan van Jogja; verder behoorden hiertoe onder meer Anak Agoeng en Roem. Van Nederlandse kant nam Lovink, de Hoge Vertegenwoordiger van de Kroon, aan de plechtigheid deel, in gezelschap van de leden van zijn gouvernement en een groot aantal gasten, onder wie ook de zo juist aangekomen Hoge Commissaris van Nederland bij de RVI, H.M. Hirschfeld. Buiten het paleis had zich een grote menigte verzameld. Lovink en de sultan ondertekenden een proces-verbaal van bestuursoverdracht en hielden beiden een toespraak. Daarna luisterde men naar een radiouitzending van dat deel van de plechtigheid in Amsterdam waarin koningin Juliana haar rede uitsprak. Na afloop hiervan gingen allen naar de voorkant van het paleis voor de vlaggenwisseling. Terwijl het Nederlandse volkslied gespeeld werd daalde de rood-witblauwe vlag op het dak van het paleis langzaam omlaag. Er klonk even gefluit en gejoel uit de menigte, maar daarna werd het doodstil. Voor alle aanwezige Nederlanders en ook voor veel Indonesiërs was dit het meest aangrijpende onderdeel van de plechtigheden. Vervolgens ging de rood-witte vlag boven het paleis omhoog onder de klanken van het 'Indonesia Raya', dat door uitbundig gejuich overstemd werd. Meteen hierna stapte Lovink in de auto die hem naar het vliegveld bracht voor zijn terugkeer naar Nederland.

Omstreeks dezelfde tijd vond in het presidentieel paleis in Jogja de plechtigheid plaats tot overdracht van de soevereiniteit van de oude Republiek, de RI, aan de nieuwe Republiek, de RVI. Dit gebeurde in de vorm van een bijzondere zitting van het Werkcomité van het KNIP. Wegens zijn benoeming tot president van de RVI legde Soekarno zijn presidentschap van de RI tijdelijk neer; de voorzitter van het KNIP, Assaat, werd nu tot 'drager van de presidentiële functie' van de RI benoemd. Men luisterde eerst naar de radiouitzendin- 
gen van de ceremonies in Amsterdam en in Djakarta. Daarna droeg Assaat de soevereiniteit van de Republiek over aan de RVI, vertegenwoordigd door haar president Soekarno. Het hoogtepunt van de plechtigheid was dat Assaat aan Soekarno een houten kistje overhandigde met daarin de vlag die op 17 augustus 1945 bij de uitroeping van de onafhankelijkheid voor het huis Pegangsaän Oost 56 gehesen was.

De volgende ochtend, 28 december, vlogen Soekarno en zijn gevolg in twee vliegtuigen van de nationale luchtvaartmaatschappij Garuda naar Djakarta. Soekarno had een gevolg meegenomen waarin niet alleen verschillende geledingen van de Indonesische samenleving vertegenwoordigd waren maar ook verschillende fasen van de nationale vrijheidsstrijd. Onder meer behoorden daartoe Ki Hadjar Dewantoro en Soetardjo Kartohadikoesoemo. Al in 1912 was Dewantoro (die toen nog Soewardi Soerjaningrat heette) één van de leiders van de Indische Partij geweest, de eerste politieke partij die naar onafhankelijkheid voor Indonesië streefde (zie pp. 161-3). In 1932 had hij het verzet tegen de 'wilde-scholen-ordonnantie' geleid, de enige vooroorlogse actie waarin de nationale beweging een overwinning op het gouvernement behaald had (zie p. 221). Soetardjo was de indiener geweest van de in 1936 door de Volksraad aangenomen petitie waarin gevraagd werd aan Nederlands-Indië langs de weg van geleidelijke hervorming zelfstandigheid toe te kennen binnen het Koninkrijk der Nederlanden; de Nederlandse regering had deze petitie afgewezen met steun van een grote meerderheid van het parlement (zie pp. 234-8). Na de aankomst in Djakarta hield Soekarno bovenaan de vliegtuigtrap allereerst het kistje met de historische vlag omhoog; dit werd daarna met een speciaal motorescorte naar het paleis gebracht.

Intussen waren honderdduizenden in Djakarta de straat opgegaan om de intocht van de president mee te maken. Volgens het oorspronkelijke plan zou Soekarno eerst naar het huis aan Pegangsaän Oost 56 gaan dat hij in de nacht van 3 op 4 januari 1946 verlaten had (zie p. 436) en pas daarna naar het paleis. Maar omdat men niet over voldoende politie beschikte om op een zo lang traject de orde te handhaven koos men voor de kortste route van het vliegveld naar het paleis. Staande in een open auto kwam Soekarno in de mensenzee maar langzaam vooruit. Toen hij het paleis eindelijk bereikt had doorbrak de menigte alle cordons, stroomde de paleistuin binnen en drong de paleistrappen op. Het was de bedoeling van de PPN geweest Soekarno ceremonieel te ontvangen op een podium dat daartoe aan de voorkant opgericht was, maar het bleek niet meer mogelijk dit podium te bereiken. Op het bordes van het paleis stelde men haastig enige microfoons op, Anak Agoeng sprak een kort welkomstwoord uit en daarna richtte Soekarno zich tot de menigte met een redevoering waarin hij alle registers van zijn volksmennerskunst opentrok. Hij eindigde met een fanatieke oproep de strijd voort te zetten opdat NieuwGuinea voor eind 1950 met Indonesië herenigd zou worden. 
Hoe opwindend Soekarno's rede ook was, zijn gehoor werd er niet agressief door, maar ging ordelijk en tevreden uiteen. Er deed zich op deze dag en de volgende dagen in Djakarta geen enkel incident voor. Tenslotte hield Soekarno op de avond van 29 december een grote ontvangst die bezocht werd door ruim vijfduizend gasten, voor het grootste deel Nederlanders. Nooit was er in de koloniale tijd in dit paleis een zo druk bezochte receptie geweest.

\section{Terugblik}

De Rondetafelconferentie had het mogelijk gemaakt de koloniale verhouding tussen Nederland en Indonesië voorgoed te veranderen in een verhouding tussen twee soevereine staten. Het resultaat van de RTC paste in het kader van het akkoord van Linggadjati. Indonesië werd een bondsstaat waarin de Republiek de positie van een deelstaat innam, terwijl Indonesië en Nederland samen een Unie vormden onder de Nederlandse koningin. Op staatkundig en militair gebied had Nederland veel van zijn oorspronkelijke plannen laten varen, maar op economisch gebied had het gunstige voorwaarden verkregen voor de voortzetting van zijn activiteiten in Indonesië. Er zijn geen aanwijzingen dat de Republiek in juli 1947 of in december 1948 niet bereid geweest zou zijn Nederland even ver tegemoet te komen als nu gebeurd was. Toch had de Nederlandse regering toen gemeend dat Nederland geen andere keus had dan een militaire aanval op de Republiek. Anders gezegd: in 1947 en 1948 had aan Nederlandse kant de bereidheid ontbroken tot een politieke oplossing als uiteindelijk in 1949 tot stand gekomen is.

Twee factoren speelden daarbij een rol. Ten eerste konden de meeste Nederlanders de eerste jaren nog niet aan de gedachte wennen dat Indonesië werkelijk onafhankelijk zou worden. Daarom bleven de Nederlandse beleidsmakers ook na het akkoord van Linggadjati streven naar staatsrechtelijke en militaire waarborgen om Nederland nog lange tijd een tastbare invloed op de gang van zaken binnen Indonesië te geven. Ten tweede beschikte Nederland daar in 1947 en 1948 over een grote strijdmacht (waarvan de aanwezigheid op zichzelf had bijgedragen tot de tegemoetkomingen van de Republiek in Linggadjati). Dit werkte de gedachte in de hand dat Nederland zijn militairtechnische overwicht kon benutten om de nagestreefde waarborgen te verkrijgen. Het Nederlandse offensief van december 1948 had de definitieve 'proef op de som' gevormd; de mislukking ervan had de weg geopend naar een politieke oplossing zonder militaire drukmiddelen.

Door een en ander was de dekolonisatie van Indonesië anders verlopen dan die van de meeste andere Aziatische koloniën. India, Pakistan, Birma, Ceylon, Cambodja, Laos en de Filipijnen waren in deze zelfde periode onafhankelijk geworden zonder een militaire krachtmeting met hun vroegere kolonisatoren. 
In al deze gevallen woog echter de psychologische betekenis van deze gebieden voor de bevolking van het koloniale 'moederland' veel minder zwaar dan die van 'Nederlands-Indië' voor de bevolking van Nederland. Verder waren deze vreedzame dekolonisaties soms gevolgd door hevige interne conflicten; in het geval van India en Pakistan hadden die zelfs een half miljoen mensenlevens gekost. Naast Indonesië was Vietnam het enige andere Aziatische land waar een koloniale macht in oorlog was geraakt met een onafhankelijkheidsbeweging, maar de politieke situatie verschilde hier aanzienlijk. De Vietnamese republiek maakte deel uit van de wereldwijde communistische beweging, terwijl de Indonesische republiek juist een communistische machtsgreep onderdrukt had toen Nederland haar ten tweede male aanviel.

Het gewapende conflict tussen de Indonesische onafhankelijkheidsbeweging en het vroegere koloniale heersersland had bijna vier jaar geduurd en aan beide zijden schade en leed berokkend. Hoewel Nederland verarmd uit de Tweede Wereldoorlog gekomen was, had het grote financiële offers gebracht om een strijdmacht in Indonesië op te bouwen. Ondanks een dringende behoefte aan arbeidskrachten voor de wederopbouw in eigen land had het ruim honderdtwintigduizend jonge mannen aan het Nederlandse arbeidspotentieel onttrokken en als militairen in Indonesië ingezet. Daartoe waren die mannen gedurende enige jaren uit hun gezin, hun werk en hun vertrouwde omgeving weggehaald. Aan Indonesische kant waren de schadelijke gevolgen van het conflict nog ingrijpender. Terwijl de economie van Indonesië door de Japanse bezetting al ernstig ontredderd was, belette het conflict in grote delen van Java en Sumatra niet alleen het herstel, maar veroorzaakte het ook verdere achteruitgang. Dit was onder meer te wijten aan de Nederlandse blokkade van Republikeins gebied en aan de Republikeinse vernielingen in het kader van de 'verschroeide-aarde'-strategie. Bovendien was het Indonesische arbeidspotentieel aangetast door de deelname van honderdduizenden aan de gewapende strijd, deels in het reguliere Republikeinse leger, deels in autonome strijdgroepen. Daarbij hadden veel van die strijders grote ontberingen geleden en waren zij voor hun levensonderhoud afhankelijk geraakt van steun uit de plaatselijke bevolking.

Op het punt van verliezen aan mensenlevens liepen de gevolgen van het conflict voor de twee partijen ver uiteen. Tussen het begin van de vijandelijkheden in najaar 1945 en de wapenstilstand van augustus 1949 waren aan Nederlandse kant ruim vijfentwintighonderd militairen gesneuveld. Daarentegen had het Nederlandse militaire optreden aan Indonesische kant een veel groter aantal dodelijke slachtoffers gemaakt, zowel onder de strijders als onder de burgerbevolking. Volgens Nederlandse militaire schattingen gaat het om een getal in de orde van grootte van honderdduizend. Overigens had het geweld in Indonesië gedurende de eerste vier jaar na de Tweede Wereldoorlog aan nog veel meer Indonesiërs het leven gekost. Daartoe behoorden slachtof- 
fers van de bersiapterreur in 1945-1946, slachtoffers van onderlinge conflicten zoals die van de Republikeinse regering met de Daroel Islam en met Moeso en diens aanhang, en tenslotte velen die in het kader van de guerrilla-strijd gedood waren wegens medewerking met het Nederlandse gezag. Wat de laatste categorie betreft vormde het aantal aldus door guerrillastrijders uit de weg geruimde Indonesiërs waarschijnlijk een veelvoud van de door Indonesiërs gedode Nederlandse militairen.

Gelet op het leed dat de militaire krachtmeting tussen Nederland en de Indonesische vrijheidsbeweging had aangericht, is het opmerkelijk dat het conflict niet had geleid tot bittere haatgevoelens van volk tegen volk. Hierbij valt te bedenken dat de Nederlandse militairen zichzelf nooit als vijanden maar juist als beschermers van de Indonesische bevolking hadden beschouwd. Bovendien hadden zowel die militairen als de Nederlanders in Europa gedurende de laatste jaren steeds meer begrip gekregen voor het Indonesische verlangen om baas in eigen huis te zijn. Daarentegen was het vooral verrassend dat de houding van de meeste Indonesiërs tegenover het Nederlandse volk eind 1949 niet door gevoelens van verbittering en wrok beheerst werd. Ten dele valt dit te verklaren uit het feit dat zij zichzelf konden zien als overwinnaars in de strijd tegen de vroegere koloniale heersers. Die overwinning gaf bovendien zin aan de gebrachte offers en droeg bij tot de Indonesische natievorming. Het besef dat de nationale onafhankelijkheid niet geschonken maar veroverd was versterkte het zelfvertrouwen en het gevoel van eigenwaarde van de Indonesische bevolking. Aan de andere kant waren onder die bevolking nog niet alle wonden geheeld die daar in de afgelopen jaren door onderlinge verdeeldheid waren veroorzaakt. Zowel binnen Nederland als binnen de Republiek Indonesië had sinds het najaar van 1945 een hevige richtingenstrijd gewoed over de aanpak van het conflict. In beide gevallen ging het om de keuze tussen wapengeweld of het doen van concessies. Zowel bij de Nederlanders als bij de Indonesiërs leek zich in die jaren meer vijandigheid te hebben gericht op de interne tegenstanders dan op de externe tegenpartij.

\section{Aantekeningen bij hoofdstuk VIII}

\section{Literatuuroverzicht}

De in dit hoofdstuk beschreven gebeurtenissen hebben zich afgespeeld in het jaar 1949. Voor de literatuur hierover valt in de eerste plaats te verwijzen naar een aantal al eerder genoemde boeken, namelijk Kahin 1952, Smit 1952 en 1962, Taylor 1960, Nasution 1979, Bank 1983, L. de Jong 1988 en Van den Doel 2000. Enige werken die meer specifiek op deze periode betrekking hebben zijn Het laatste jaar van de Indonesische vrijheidsstrijd 1948-1949 door T.B. Simatupang (1985), 'Renville' als keerpunt in de Nederlands-Indonesische onderhandelingen door Ide Anak Agung Gde Agung (1980), Minister Stikker en de soevereiniteitsoverdracht aan Indonesië door L.G.M. Jaquet (1982), 
Het laatste jaar van Nederlands-Indie door J.G. de Beus (1987) en Het einde in zicht door P.J. Drooglever en M.J.B. Schouten (1999). Wat interne documenten betreft wordt de periode bestreken door de delen XVI tot en met XX van de bronnenpublicatie NIB (1992-1996). Sommige van de in dit hoofdstuk vervatte gegevens zijn ontleend aan dagbladen uit de beschreven periode. Verder heb ik bij het schrijven van dit hoofdstuk gebruik gemaakt van eigen herinneringen en aantekeningen uit 1949-1950 toen ik zelf in Batavia/Djakarta woonde.

\section{De militaire situatie na het tweede Nederlandse offensief}

Zie Groen 1991:171-236, vooral 231-6, en Simatupang 1985, vooral 59-63. Voor Princen's eigen relaas over zijn desertie zie Princen 1995:83-109. Over Spoor's verwachting dat de guerrilla spoedig zou uitdoven zie Groen 1991:112-3, 145, 178 en Gase 1986:2845. Over de successen van de guerrilla zie ook NIB XVIII:127-8, Van Doorn en Hendrix 1993:193-200 en L. de Jong 1988:962-7. Over de Daroel Islam zie Van Dijk 1981:90-2, Groen 1991:204 en Simatupang 1985:108-9. Over Tan Malaka zie L. de Jong 1988:961-2, Groen 1991:202 en Poeze 2007:1401-94. Over de Republikeinse aanval op Jogja zie L. de Jong 1998:967-8 en NIB XVIII:1-2.

\section{De politieke situatie na het tweede Nederlandse offensief}

Over het verzuim van de Nederlandse regering om een duidelijk politiek doel voor het tweede offensief vast te stellen zie Jaquet 1982:157-8 en Groen 1991:168, 174. Over het motief van Drees zie Drees 1962:239-41. Over de uiteenlopende opvattingen binnen de Nederlandse regering zie onder meer Smit 1962:144, Jaquet 1982:161 en Bank 1983:399. Voor de tekst van de Amerikaanse waarschuwing zie NIB XVI:56-8; voor de voorspelling van Sassen NIB XVI:66.

Nederlands aanbod tot vervroegde overdracht van de soevereiniteit

Over het meningsverschil tussen Drees en Beel over de benadering van de Republikeinse leiders zie NIB XVII:216-7. Voor de brief van Beel aan Soekarno zie BZ 1950:100.

Voor de resolutie van de VN-Veiligheidsraad van 28 januari zie NIB XVII:709-11; voor een Nederlandse vertaling hiervan zie BZ 1949b:509-12. Over de ontvangst van Soekarno op Bangka zie L. de Jong 1988:970-1. Over de BFO-contactcommissie zie Anak Agung 1980:252. Over het bezoek van de UNCI zie NIB XVII:592-3.

Voor de oorspronkelijke opzet van het plan-Beel zie NIB XVII:257-8. Voor het gewijzigde plan NIB XVII:612 (de voornaamste wijziging staat daar in een bijzin tussen haakjes). Over de onenigheid in februari tussen de Nederlandse ministers onderling en tussen de regering en Beel zie Jaquet 1982:197-223 en Bank 1983:411-22.

Over het bezoek van Koets aan Bangka zie NIB XVIII:13-4 en BZ 1950:109. Over het bezoek van de BFO-delegatie aan Bangka zie Anak Agung 1980:265-6. Over het besluit van de BFO-vergadering van 3-4 maart en Beel's reactie daarop zie Anak Agung 1980:268-71 en NIB XVIII:28-9. Voor de tekst van het antwoord van Soekarno aan Beel zie NIB XVIII:37-8 en BZ 1950:107-8.

\section{Akkoord tussen Roem en Van Roijen}

Over de bereidheid van de Nederlandse regering tot een compromis over de terugkeer naar Jogja zie NIB XVIII:86-8. Voor de raadpleging van parlementsleden NIB 
XVIII:62-6. Voor de berichtgeving van Beel NIB XVIII:247-8; zie ook De Beus 1987:117. Voor Spoor's mening over de 'Soekarno-kliek' zie NIB XVIII:273-4, voor zijn mening over de laatste fase van de contra-guerrilla NIB XVIII:367. Zie over de toekomstvisie van Spoor ook De Moor 1999:405-6. Over uitstel van de troepenvermindering tot 1951 zie Groen 1991:219. Voor het regeringsbesluit over de repatriëring van de oorlogsvrijwilligers en de 7 December-divisie zie NIB XVIII:263. Over de veranderde opstelling van de ondernemers zie Bank 1983:353 en L. de Jong 1988:973.

Voor de procedurele richtlijn van de Veiligheidsraad van 23 maart zie NIB XVIII:228. Voor het antwoord van Roem aan de UNCI zie NIB XVIII:323. Voor het oordeel van Van Roijen over Spoor NIB XVIII:450. Voor de verklaringen van Roem en Van Roijen van 7 mei NIB XVIII:596-7; voor de Nederlandse vertaling hiervan zie BZ 1950:392-3. Voor het verzet van Spoor en Beel zie NIB XVIII:575-7, 586-8. Voor de machtiging van de Nederlandse regering aan Van Roijen NIB XVIII:594-5. Over de reacties in Nederland zie L. de Jong 1988:986. Voor de officiële reactie van Sjafroeddin zie NIB XVIII:646. Over de vergaderingen van de voorbereidende conferentie van 22 juni en 1 augustus zie NIB XIX:128-42, 420-1.

\section{Terugkeer van Soekarno en Hatta in Jogjakarta}

Over de uittocht uit Jogja zie NIB XVIII:650, 750, NIB XIX:214 en Simatupang 1985:156. Over de terugkeer van Hatta en Soekarno zie Simatupang 1985:158-61; over de terugkeer van Soedirman zie Simatupang 1985:182-4; over de kabinetszitting van 13 juli zie Simatupang 1985:185-6. Voor de gewijzigde samenstelling van het kabinet zie Hatta 1981:308. Over de veiligheid in Jogja zie NIB XIX:326, 349. Over het bezoek van Van Roijen aan Jogja NIB XIX:317-9.

\section{Akkoord tussen de Republiek en de federalisten}

Over de Inter-Indonesische Conferentie zie Anak Agung 1980:298-303. Voor de besluiten ervan zie NIB XIX:357-9, 432-41. De benaming Republiek der Verenigde Staten van Indonesië voor de toekomstige soevereine federatie was intern ook al vermeld in de eerste versie van het plan-Beel, maar in het openbaar was Nederland de benaming Verenigde Staten van Indonesië (VSI) blijven gebruiken. Over het eerbetoon voor wijlen Ratoelangie zie NIB XIX:406.

\section{Het derde bestand tussen Nederland en de Republiek}

Over de aanvankelijke bezwaren van de Nederlandse legerleiding en de Nederlandse regering tegen de ontworpen bestandsregeling zie onder meer NIB XVIII:709-10 en NIB XIX:8, 41, 113. Voor de op 22 juni voorlopig overeengekomen bestandsregeling NIB XIX:133-9. Over de vergadering van de militaire en politieke top van de Republiek zie Simatupang 1985:187. Over de slotvergadering van de voorbereidende conferentie zie NIB XIX:420-1. Voor de definitieve tekst van de bestandsregeling zie BZ 1950:17588; voor de Nederlandse vertaling BZ 1950:394-405.

Over de 'bloedbruiloft van Tjilatjap' zie Excessennota 1995:116-8; vergelijk NIB XX:830. Voor de reactie van Lovink wegens de aanval op Solo zie NIB XIX:512. Over de executie van Monginsidi NIB XIX:661, 750-1, 770.

Over de instelling van subcommissies van de gemengde bestandscommissie zie NIB XIX:656-8, 751. Over de afbakening van patrouillegebieden NIB XIX:389-90, 397-8 en NIB XX:94. Over de aan Nederlandse kant gerezen spanningen zie onder meer 
NIB XIX:502, 590; vergelijk Van den Doel 2000:311, 313-4 en De Beus 1987:134-141. Volgens De Beus zouden de Nederlandse troepencommandanten in een vergadering met Lovink zelfs hebben gepleit voor een derde politionele actie (De Beus 1987:144-6). Ik kan dit moeilijk geloven. In de NIB-serie is geen verslag van zo'n vergadering te vinden. Wel bevat NIB XX:121-4 een memorandum van kolonel Mollinger van 1 oktober 1949 waarin gerept wordt van 'uitschakeling van Djocja'; naar mijn mening is dit echter geen serieus pleidooi voor een derde politionele actie, maar een in dramatische vorm gegoten betoog dat het voor de Nederlandse troepen de hoogste tijd was om gebied te gaan ontruimen. Ook Bouman hecht geen geloof aan het verhaal van De Beus (zie Bouman 1995:316, noot 367).

Zie over het Nederlandse belang bij een solide positie van de Republiek onder meer NIB XIX:545, 657, 717 en NIB XX:7. Zie over de ontruiming van door Nederland bezette gebieden ook Kawilarang 1993:141-8. Over de Nederlandse bevoorrading en financiering van de TNI zie NIB XIX:656 en NIB XX:162, 238-40, 338-9, 554, 573. Over de vrijlating van gevangenen zie NIB XIX:751 en NIB XX:687.

\section{De Rondetafelconferentie in Den Haag}

Voor het akkoord van 22 juni over de RTC zie NIB XIX:139-42; voor de Nederlandse vertaling hiervan zie BZ 1950:406-8. Voor een overzicht van de deelnemers aan de RTC zie NIB XIX:778-9. Voor de Nederlandse voorstellen over de Unie NIB XIX::6417. Over het verloop van de onderhandelingen zie Meijer 1994:42-51. Voor de definitieve tekst van de Mantelresolutie, het Uniestatuut en de Overgangsovereenkomst zie NIB XX:859-61. Voor de volledige Engelse tekst van de RTC-overeenkomsten zie BZ 1950:293-388. Voor de volledige tekst in drie talen zie Staatsblad 1949 J 570. De Engelse tekst van de VSI-grondwet is ook afgedrukt in A.B. Nasution 1992:450-86.

Het externe zelfbeschikkingsrecht voor Indonesische minderheden

Voor de instructies van Helfrich aan Pinke zie NIB VIII:71 en NIB X:180. Voor de houding van het gouvernement en de regering tegenover de PTB en de Twapro zie NIB VIII:491-4, NIB IX:364, NIB XIII:292-4, NIB XVIII:313, NIB XIX:9, 104, 347. Over de representativiteit van deze organisaties zie NIB XVIII:21, 219, 311, 548-9 en NIB XIX:109. Over het Nationaal Comité Handhaving Rijkseenheid zie Hekman 1981:64-5. Over het streven om het meest oostelijke deel van de archipel binnen het Koninkrijk te houden vergelijk Van Kaam 1977:104-5 en Bosscher en Waaldijk 1985:31-6. Over de wens van de PTB en de Twapro tot volwaardige deelname aan de RTC zie NIB XX:366, 469. Over de behandeling van het zelfbeschikkingsrecht in de RTC zie Anak Agung 1980:320-5. Voor de door de UNCI voorgestelde compromisformule zie NIB XX: 869 (Overgangsovereenkomst, artikel 2, lid 2). Zie ook Chauvel 1990:282-90, 296-8.

\section{De kwestie Nieuw-Guinea}

Er is veel literatuur over dit onderwerp, waaronder Nieuw-Guinea als schakel tussen Nederland en Indonesië door F.J.F.M. Duynstee (1961), The trauma of decolonization door A. Lijphart (1966), De kwestie Nieuw-Guinea door P.B.R. de Geus (1984), Misleiding of zelfbedrog door R. Gase (1984), The New Guinea debacle door C.L.M. Penders (2002) en Een daad van vrije keuze door P.J. Drooglever (2005).

Voor de verklaring van Van Mook in Denpasar zie Van Goudoever 1947:46; zie ook NIB VI:634. Voor de verklaring van Drees in de ministerraad in maart 1949 zie NIB 
XVIII:198. Voor de verklaring van Van Maarseveen in de ministerraad in juni 1949 zie NIB XIX:26; zie ook De Geus (1984):47-8. Over het parlementair-rekenkundig motief zie NIB XX:140. Voor het gesprek van Van Maarseveen met departementshoofden in Batavia zie NIB XIX:172-5. Voor het betoog van Van Mook van 14 juli 1949 zie Nieuwe Rotterdamse Courant van 16 juni 1962:7. Voor het gesprek van Van Roijen met Soekarno zie NIB XIX:318.

Over de opstelling van het parlement van Oost-Indonesië zie NIB XX:447. Over de behandeling van de kwestie Nieuw-Guinea in de RTC NIB XX:185-8, 351-2, 385, 398-9, 467-9, 476-7, 486-90. Voor het eenstemmig oordeel van het gouvernement in Batavia NIB XX:96-7, 159-60. Voor de mening van Van Roijen zie NIB XIX:539. Zie ook Anak Agung 1980:314-7 en Drooglever 2005:159-65, 170-4.

Over de psychologische achtergronden van de kwestie Nieuw-Guinea zie NIB XIX:503, Lijphart 1966:286-8 en L. de Jong 1988:1078.

\section{De tekst van het Charter van Soevereiniteitsoverdracht}

Voor het Nederlandse ontwerp voor het Charter zie NIB XIX:639-40.

Ik heb in deze paragraaf geschreven dat men uit de tekst van het Charter kan concluderen dat de soevereiniteitsoverdracht ook op Nieuw-Guinea betrekking had. Mijn persoonlijke mening is dat men dit niet alleen kan maar ook moet concluderen. Dit meen ik al sinds ik eind 1949 voor het eerst de tekst van het Charter las, terwijl ik toen nog geen kennis droeg van de oorspronkelijk door Nederland tijdens de RTC voorgestelde teksten die in de slotfase van de conferentie plaats gemaakt hadden voor formuleringen in overeenstemming met de Indonesische zienswijze.

In Nederland hebben enige conservatieve parlementsleden de formuleringen van het Charter ernstig bekritiseerd tijdens de parlementaire behandeling van de RTCakkoorden in december 1949. Er waren toen al berichten verschenen over uitlatingen van Hatta en van Anak Agoeng die er op duidden, dat de soevereiniteitsoverdracht volgens hen ook Nieuw-Guinea zou insluiten en dat alleen het beheer van het gebied voorlopig bij Nederland zou blijven. Minister Van Maarseveen sprak die berichten tegen en hield vast aan zijn standpunt, dat de toen geldende status quo nu eenmaal inhield dat Nieuw-Guinea onder Nederlandse soevereiniteit viel en dat artikel 2 van het Charter daarom betekende dat die soevereiniteit bij Nederland bleef berusten. In de Tweede Kamer noemde het CHU-lid F.H. van de Wetering de stelling van de regering dat artikel 2 een uitzondering op artikel 1 inhield 'uiterst aanvechtbaar'. Oud-minister Welter was evenmin overtuigd door de redenering van de regering en vreesde dat, als het Internationale Gerechtshof hierover zou moeten oordelen, Nederland de zaak zou kunnen verliezen. In de Eerste Kamer kwam het CHU-lid G. Kolff uitvoerig op de kwestie terug. Naar zijn mening verschaften de formuleringen van de RTC aan Indonesië een stevige rechtsgrond voor de stelling dat het krachtens het Charter de volle soevereiniteit over Nieuw-Guinea verwierf. Kolff knoopte aan zijn betoog een voorspelling vast: hij waarschuwde dat de verschillende uitleg van het Charter ten aanzien van Nieuw-Guinea zou leiden tot een conflict tussen Nederland en Indonesië dat de stemming grondig zou bederven, zodat het doel van de RTCovereenkomst, het bereiken van een verhouding van vrede en rust tussen de beide landen, niet zou worden bereikt. Minister Van Maarseveen reageerde geprikkeld op de kritiek en zei niet in te zien welk Nederlands belang ermee gemoeid was om zo hardnekkig twijfel te willen wekken omtrent het standpunt van de regering. 
$\mathrm{Na}$ de soevereiniteitsoverdracht is men er in het parlement algemeen van uitgegaan dat de Nederlandse soevereiniteit over Nieuw-Guinea in stand gebleven was. De enige mij bekende juridische uitleg van het Charter die met mijn opvatting overeenstemt is te vinden in een artikel van dr. J.W.H. Leslie Miller in het maandblad Socialisme en Democratie van oktober 1956. Daarentegen heeft geen enkele gezaghebbende Nederlandse jurist ooit uitdrukkelijk het standpunt ingenomen dat Nederland na 1949 niet langer de soevereiniteit over Nieuw-Guinea bezat. Wel heeft prof. Röling de officiële Nederlandse interpretatie aanvechtbaar genoemd (zie Röling 1958:18-25, 28-34, 83-5) en heeft prof. Duynstee gesteld dat het Charter opzettelijk zo geredigeerd was dat er ruimte bleef voor twee tegenstrijdige interpretaties (zie Duynstee 1961:1736). Ik blijf van mening dat de op de RTC overeengekomen formules géén ruimte lieten voor de officiële Nederlandse interpretatie.

Die officiële interpretatie wordt onder meer gelogenstraft door de wijzigingen die op de RTC zijn aangebracht in de oorspronkelijk door de Nederlandse delegatie voorgestelde teksten. Ik zie hier een parallel met de manier waarop Nederland artikel 15 van de overeenkomst van Linggadjati uitgelegd heeft (zie pp. 521-2). De in 1946 oorspronkelijk door de Nederlandse delegatie voorgestelde formulering van dat artikel had een erkenning ingehouden van de staats- en volkenrechtenlijk positie van het Koninkrijk der Nederlanden, maar op wens van de Republikeinse delegatie was men een andere tekst overeengekomen waar die erkenning niet meer in voorkwam. Niettemin heeft Nederland zich zowel bij de uitleg van Linggadjati als bij die van de soevereiniteitsoverdracht steeds gedragen alsof de oorspronkelijk van Nederlandse kant voorgestelde formuleringen gehandhaafd waren gebleven.

Bij mijn (in Nederland vrijwel niet gedeelde) opvatting over de juridische betekenis van de soevereiniteitsoverdracht moet ik wel enkele kanttekeningen maken.

Ten eerste hebben officiële vertegenwoordigers van Indonesië soms zelf uitspraken gedaan die niet met die opvatting strookten. Zij verlangden bijvoorbeeld dat Nederland alsnog de soevereiniteit over Nieuw-Guinea aan Indonesië zou overdragen, in plaats van te verlangen dat Nederland alsnog zijn soevereiniteitsaanspraak ten aanzien van Nieuw-Guinea zou laten varen. Ten tweede heeft Indonesië zich nooit bereid getoond de juridische kwestie van de soevereiniteit over Nieuw-Guinea ter beslechting voor te leggen aan een onpartijdig rechterlijk orgaan zoals het Internationaal Gerechtshof. Het voerde dan aan dat het geschil met Nederland over NieuwGuinea niet een juridische maar een politieke kwestie was.

Daar staat tegenover dat de regering en het parlement van Nederland zelf zich in 1962 volstrekt inconsequent hebben opgesteld door toen geen formele daad nodig te achten voor het overdragen van de vermeende Nederlandse soevereiniteit over Nieuw-Guinea aan Indonesië (zie pp. 754 en 759-60).

\section{De soevereiniteitsoverdrachten}

Over de behandeling van de RTC-akkoorden in het parlement van Oost-Indonesië zie Anak Agung 1980:342-3. Over de behandeling in het KNIP zie Poeze 2007:1601-6. Over de behandeling in het Nederlandse parlement zie Stempels 1950:225-45. Over het voorstel van het gouvernement in Batavia van 3 november zie NIB XX:543-4. Over de PPN zie Anak Agung 1980:344 en NIB XX:684, 711-3. Over de Nederlandse contactgroep NIB XX:686, 698, 712. Voor de samenstelling van het kabinet van de RVI NIB XX:834-5. 
Terwijl verscheidene historische werken melding maken van het in augustus 1949 door de Inter-Indonesische Conferentie genomen besluit, dat de RVI haar soevereiniteit ook van de in 1945 opgerichte Republiek zou ontvangen, blijkt de ceremonie op 27 december in Jogja waarin deze soevereiniteitsoverdracht plaats vond vrijwel volledig in het vergeetboek te zijn geraakt (afgezien van een summiere vermelding in Feith 1962:57). Zelfs het grote geschiedwerk Sejarah nasional Indonesia, waarvan deel VI onder redactie van Nugroho Notosusanto deze periode bestrijkt, rept er niet over. Hetzelfde geldt voor deel 11 van het geschiedwerk Sekitar perang kemerdekaan Indonesia van Nasution. L. de Jong 1988 schrijft op pg. 984 wel over een overdracht in Jogja, maar stelt die op één lijn met de bestuursoverdracht in Batavia. Dit is een misverstand. Wat in Jogja plaats vond was géén bestuursoverdracht; het bestuur over het Republikeinse grondgebied binnen de grenzen van 19 december 1948 bleef in handen van de 'oude Republiek', die juist door deze soevereiniteitsoverdracht haar eigen status veranderde in die van een deelstaat binnen de VSI.

Ook het omvangrijke en veelzijdige ere-escorte dat Soekarno bij zijn terugkeer vergezelde wordt in de mij bekende literatuur nergens vermeld.

\section{Terugblik}

Zie over een vergelijking van de concessiebereidheid van de Republiek in 1947 en 1948 met het eindresultaat van de RTC ook L. de Jong 1988:1067.

Volgens door de Nederlandse regering aan het parlement overgelegde verliescijfers zijn tussen najaar 1945 en de wapenstilstand van augustus 1949 in Indonesië 2526 Nederlandse militairen gesneuveld, van wie 1602 behoorden tot de uit Nederland uitgezonden landstrijdkrachten, 202 tot de Nederlandse marine en 722 tot het KNIL. Van die 2526 gesneuvelden vielen er 1162 in de zeven maanden na het tweede Nederlandse offensief. Nederlandse veteranenorganisaties hanteren aanzienlijk hogere getallen voor de Nederlandse verliezen in Indonesië, onder meer door daarin ook alle militairen op te nemen die als gevolg van ziekte of ongelukken overleden zijn. 
Herman Burgers - 9789004253742 Downloaded from Brill.comఠ4/26/2023 10:41:26AM via free access 

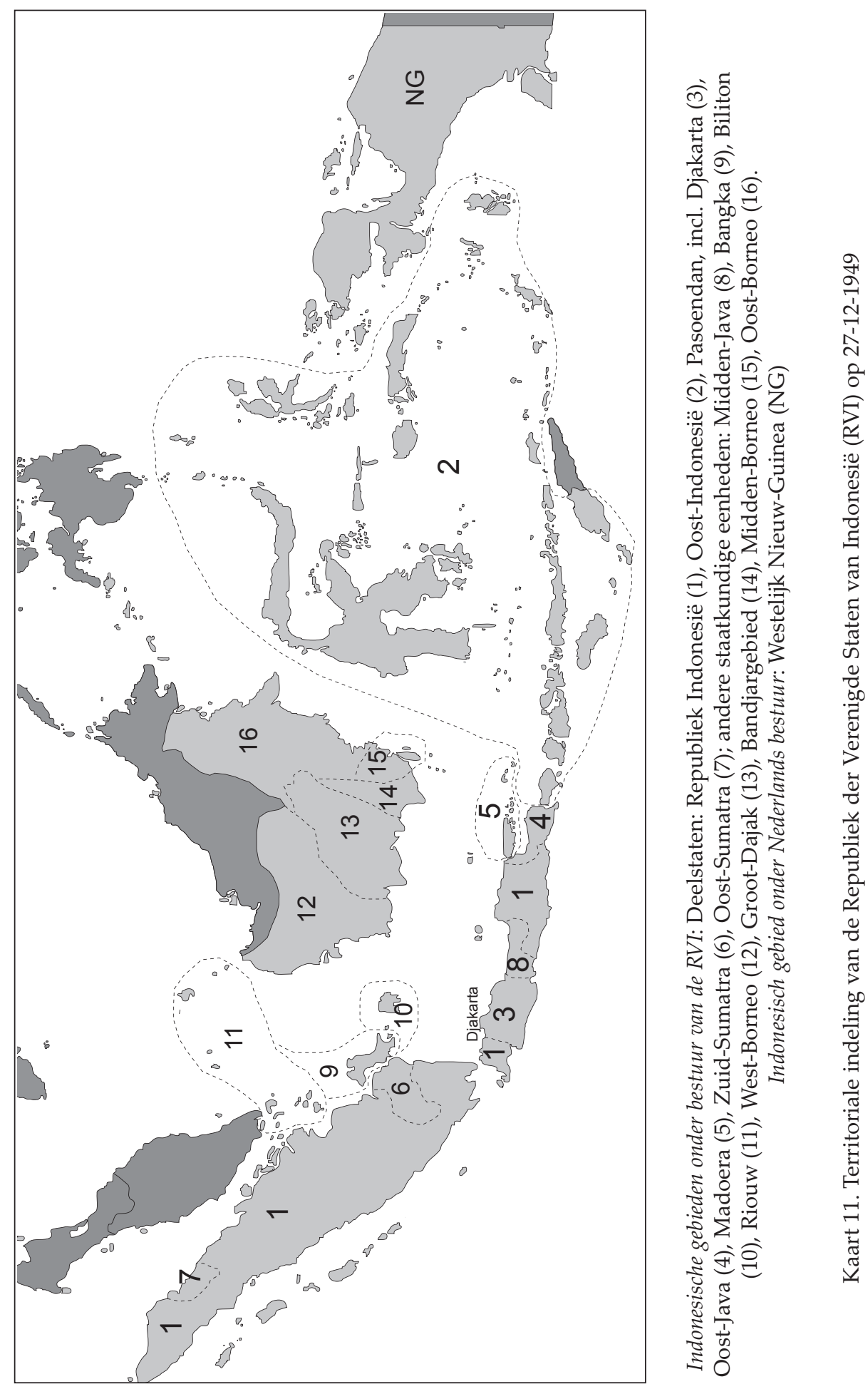